\title{
The taxonomy and biogeography of the viridis group of the genus Baeturia Stål, 1866 (Homoptera, Tibicinidae)
}

\author{
A.J. de Boer \\ Institute of Taxonomic Zoology (Zoological Museum), University of Amsterdam, P.O. Box 4766, 1009 \\ AT Amsterdam, The Netherlands
}

Keywords: Baeturia, viridis group, taxonomy, biogeography, New Guinea

\begin{abstract}
The viridis group is proposed for a supposedly monophyletic group of seven New Guinean species of the cicada genus Baeturia Stål, 1866. Three species (B. brongersmai Blöte, B. rufula $B l o ̈ t e$, and $B$. viridis $B l o ̈ t e)$ are redescribed and four species ( $B$. furcillata, B. karkarensis, B. lorentzi, and B. turgida) are described as new to science. A key to the males is provided. The phylogenetic position of the viridis group within the genus Baeturia is discussed. The distribution of shared characters suggests a subdivision of the group into two subgroups. One subgroup is restricted to southern and western Irian Jaya, while the other is distributed along the coastal mountain ranges of northern New Guinea, including Karkar Island.
\end{abstract}

\section{Résumé}

On propose le nom viridis pour un groupe vraisemblablement monophylétique de sept espèces de Nouvelle Guinée appartenant au genre de Cigales Baeturia Stål, 1866. Trois espèces (B. brongersmai $\mathrm{Blöte}, \boldsymbol{B}$. rufula Blöte et $\boldsymbol{B}$. viridis Blöte) sont redécrites, tandis que quatre autres (B. furcillata, B. karkarensis, B. lorent$z i$ et $B$. turgida) sont décrites comme nouvelles pour la science. On fournit une clé pour les mâles. La position phylogénétique du groupe viridis dans le cadre du genre Baeturia est discutée. La distribution des caractères partagés suggère une sous-division du groupe en deux sous-groupes, dont l'un est restreint aux parties S. et $\mathrm{O}$. d'Irian Jaya, tandis que l'autre est distribué le long des chaînes de montagnes côtières de Nouvelle Guinée du nord, l'île Karkar y comprise.

\section{Introduction}

Present-day distribution of cicadas in the Malay Archipelago appears to reflect the geological history of the area. Areas of endemism, as recognized from the distributions of monophyletic groups, coincide with areas demarcated by historic barriers of different kinds (Duffels, 1986; Duffels \& De Boer, 1990). The phylogenetic relation between endemic groups is supposed to reflect mainly the different geological relationships of their distribution areas through time. The cicada genus Baeturia Stål, 1866 is widely distributed in New Guinea and adjacent islands. Phylogenetic and biogeographic study of this genus might contribute to a better understanding of the complex geological history of this area and the relationships between its geological components.

The genus Baeturia as currently understood is not considered monophyletic, but species groups of supposedly monophyletic origin can be recognized. Revisions of three such species groups have been published: the nasuta group by De Boer (1982), the conviva group by De Boer (1986) and the bloetei group by De Boer (1989).

The present paper contains a revision of the Baeturia viridis group, a presumably monophyletic group of seven species related to $B$. viridis Blöte, 
1960. This group can be recognized by the shape of the lateral lobes of the pygofer, which is supposed to be synapomorphic. Other pygofer characters suggest a sister-group relationship with the nasuta group.

The viridis group is endemic to New Guinea. A subdivision into two geographically separated subgroups is suggested by several shared characters. The viridis group comprises $B$. brongersmai Blöte, 1960, B. rufula Blöte, 1960, B. viridis Blöte, 1960, and four species new to science: $B$. furcillata, $B$. karkarensis, B. lorentzi, and B. turgida.

\section{Material and methods}

The material examined for this study is preserved in the following institutions:

BMNH Natural History Museum (formerly: British Museum (Natural History)), London

BPBM Bernice P. Bishop Museum, Honolulu

KBIN Koninklijk Belgisch Instituut voor Natuurwetenschappen, Brussels

MZB Museum Zoologicum Bogoriense, Bogor

NCSU North Carolina State University Insect Collection, Raleigh

NMW National Museum of Wales, Cardiff

RMNH National Museum of Natural History (formerly: Rijksmuseum van Natuurlijke Historie), Leiden

SMD Staatliches Museum für Tierkunde, Dresden

ZMA Institute of Taxonomic Zoology (Zoological Museum), Amsterdam

ZMB Institut für Spezielle Zoologie und Zoologisches Museum der Humboldt-Universität, Berlin

The following sources have been used for tracing the localities: Atlas van tropisch Nederland (Anonymous, 1938), The Times Atlas of the World (Anonymous, 1968) and a "List of New Guinea localities" published by the Bernice P. Bishop Museum (Anonymous, 1966).

To examine the male genitalia, the pygofer was pulled out, after overnight softening, with a sharp needle inserted between the pygofer and the 8th abdominal segment. The aedeagus was pulled out at the same time, by inserting the needle between the claspers. Body and tegmen lengths of all specimens were measured; other measurements are based on a maximum of ten specimens, if available.

\section{Phylogeny}

The monophyly of the viridis group

The species of the viridis group have well devel- oped, in most species distinctly backwards projecting, protuberances on the lateral lobes of the pygofer. These protuberances have a sharp lateral edge. The distal margin of the pygofer bends concavely to, or almost to, the apices of these protuberances.

Similar backwards projecting protuberances are found in several other species of Baeturia, but in these species the protuberances are more rounded, sometimes almost conically shaped, while the distal margin of the pygofer is either straight or slightly convex towards the base of the protuberance.

A protuberance shape similar to that of the viridis group was found in only one other, as yet undescribed, species, but several other characters of this species suggest a close relationship to $B$. guttulinervis Blöte, 1960 rather than to the species of the viridis group. This means that the monophyly of the viridis group is not beyond doubt, as it relies on the shape of the lateral pygofer lobe only, but the distribution of several other, clearly apomorphous, characters within the group confirm a close relationship between its species (see below).

\section{The phylogenetic position of the viridis group}

As stated above, several monophyletic species groups can be recognized within the genus Baeturia. A distinctly backwards projecting protuberance on the lateral lobe of the pygofer is regarded as synapomorphous for four such groups: the viridis group described here, the nasuta group (De Boer, 1982), the conviva group (De Boer, 1986), and a not yet revised species group related to Baeturia guttulinervis Blöte, 1960. Other species of Baeturia have much smaller, bluntly rounded and more laterally situated protuberances (cf. the bloetei group of De Boer, 1989); such backwards projecting protuberances do not occur in genera related to Baeturia, viz. Gymnotympana Stål, 1861, Thaumastopsaltria Kirkaldy, 1900, Chlorocysta Westwood, 1851, Cystosoma Westwood, 1842, and Venustria Goding \& Froggatt, 1904 (see De Boer, 1990).

The viridis group and nasuta group together probably form a monophyletic group on account of sharing a stout and angularly bent male caudodor- 
sal beak. In the species of these two groups, the dorsal margin of the pygofer is not continuously convex with the curvature of the caudodorsal beak, but concave at the base of the beak; the beak is truncate or bicuspidate at its apex (B. nasuta Blöte, 1960, being the only exception, with a rounded apex, $\mathrm{cf}$. De Boer, 1982) and the dorsal margin of the beak (lateral view) is concave just before reaching the apex (see arrow in Fig. 5). In the conviva group, in the species related to guttulinervis, and in some species of the bloetei group, the caudodorsal beak is continuously, or almost continuously, rounded with the pygofer, and pointed at the apex. In other species of the bloetei group, as in many other Baeturia species, the caudodorsal beak is slender and erect, either pointed or rounded at the apex. Though in some of these species the caudodorsal beak is truncate, the dorsal margin of the beak is never concave near the apex.

Seemingly in contradiction with a supposed monophyly of the nasuta group and viridis group together, the species of the viridis group share a rather massive caudodorsal beak with $B$. hardyi, $B$. quadrifida, and $B$. schulzi of the conviva group and with two undescribed species related to $B$. guttulinervis. The beak is hollow in other Baeturia species.

\section{Infra-group relationships}

Possible relationships between the species of the viridis group are indicated on account of the possession of shared characters. When appropriate, the occurrence of these characters outside the group is discussed. A phylogenetic reconstruction of the genus will be given when the revision of Baeturia is completed.

Body colouration. - B. furcillata, B. karkarensis, $B$. rufula, and $B$. turgida are reddish brown. The male abdomen is characterized by red segmental hind margins and distinct lateroventral rows of dark spots, usually on segments 3-8. $B$. rufula is unspeckled, $\boldsymbol{B}$. karkarensis, $\boldsymbol{B}$. furcillata, and $\boldsymbol{B}$. turgida are, more or less densely, brown speckled. This speckling is most dense on the head, the medial part of the pronotum, and on a middorsal band on the abdomen and the sides of tergites 7-8. Females are more intensely speckled all over; the lateroventral spots and red segmental hind margins of the abdomen are generally less distinct.

Males of $B$. brongersmai, $B$. lorentzi, and $B$. viridis are light ochraceous brown, or tinged greenish and not speckled. The hind margins of the abdominal segments are light ochraceous or green; lateroventral rows of spots on the abdomen are most distinct on segments $3-4$, but change to unpigmented patches in succeeding segments. Females of these species are often bicoloured, with green head and thorax and ochraceous abdomen.

In the bloetei group (De Boer, 1989) too, such a discrimination between speckled species, with lateroventral rows of dark spots and red segmental hind margins on abdomen, and unspeckled species, often with bicoloured females, was made. Since in some species of the bloetei group speckled and unspeckled specimens occur, the phylogenetic value of this character is considered doubtful. Other Baeturia species are generally speckled.

Shape of head. - B. brongersmai, B. lorentzi, and $B$. viridis share a broad, oblong postclypeus (Fig. 2) with a slightly convex anterior margin; the postclypeus is not swollen ventrally (Fig. 3). In these species, the head is shorter than the distance between the eyes. The other species of the viridis group share a more angularly protruding postclypeus, with strongly convex anterior margin (Fig. 51), and a distinct ventral swelling (Fig. 50). The head of these species is generally longer than the distance between the eyes.

An oblong, unswollen postclypeus is found in all species of the bloetei group. The angularly protruding and swollen postclypeus is very common in other species of Baeturia. The head is generally shorter than the distance between the eyes in the bloetei group, but often longer in other species of Baeturia.

Tegmina and wings. - In many species of Baeturia the veins of tegmina and wings bear setae. The veins of $B$. brongersmai, $B$. lorentzi, and $B$. viridis are practically bald, whereas those of $B$. furcillata, 
B. karkarensis, B. rufula, and B. turgida are densely set with long and thin setae, on upper- and underside.

Comparably densely "hairy" veins can be found in the nasuta, conviva, and guttulinervis groups, though the density of setae is variable between the species of these groups.

Shape of opercula. - The male opercula of $\boldsymbol{B}$. brongersmai, $B$. lorentzi, and $B$. viridis are almost oval, with a slightly convex distal margin. The male opercula of B. karkarensis, B. rufula, and B. turgi$d a$ are more angular to oblong, with a distinctly concave distal margin. $B$. furcillata has a much smaller erect male operculum, with straight distal margin.

Male opercula with concave distal margins are found in some species of the nasuta group. The distal margin is generally convex, however, in other species of Baeturia.

The female opercula of $B$. brongersmai, $B$. lorentzi, and $B$. viridis are rather large and curved towards the body. The female opercula of $B$. karkarensis and $B$. turgida are smaller, sickle-shaped, and erect. Of the remaining two species, no females were available.

An enlarged and curved female operculum was found in several species of the bloetei group, but most other females of the genus have small, sickleshaped, and erect opercula.

Shape of pygofer. - B. karkarensis, B. rufula, and $B$. turgida share a very characteristic pygofer; the straight distal margin of the pygofer forms sharp, though rounded angles with the straight margin of the caudodorsal beak and with the protuberance on the lateral lobe of the pygofer. In these species, the distal margin of the pygofer ends at half-length of this protuberance. In lateral view, pygofer, caudodorsal beak and protuberance form an almost triangular frame around the claspers and anal valves. The protuberances on the lateral lobes of the pygofer are very long, almost straight and directed upward, pointing to the apex of the caudodorsal beak. This pygofer shape is probably synapomorphous for these three species.

The distal margin of the pygofer is concave in $B$. brongersmai, B. furcillata, B. lorentzi, and $B$. viridis and continuously bent from the apex of the caudodorsal beak to the apex of the protuberance on the lateral lobe of the pygofer. The protuberances are much shorter in these species, and their distal halves are angularly bent upward. $B$. furcilla$t a$ differs slightly from $B$. brongersmai, $B$. lorentzi, and $B$. viridis; its distal pygofer margin is not continuous with the apex of the protuberance, but forms an almost right-angled corner at this apex (Fig. 54, arrow). In other Baeturia species the protuberances are generally slightly upcurved towards their apices.

$B$. furcillata and $B$. turgida share a bifurcate caudodorsal beak. This bifurcation is unique for these two species, but its phylogenetic value is not clear, since it corresponds to a middorsal indentation at the apex of the caudodorsal beak of several other species of the viridis group, as well as of some species of the nasuta group.

Shape of clasper. - The claspers of many, if not all, Baeturia species have a lateral crest, from dorsal to ventral, across their base. This crest is usually hidden deep inside the pygofer. In some species of the viridis group, however, it is clearly visible and sometimes even extending beyond the pygofer margin (Fig. 16, arrow). The crest is most prominent in $\boldsymbol{B}$. brongersmai, B. furcillata, B. karkarensis, $\boldsymbol{B}$. turgida, and $B$. viridis, but not visible in all specimens of these species. Such a prominent position of this crest only occurs in species of the viridis group.

$B$. brongersmai, $B$. lorentzi, and $B$. viridis share a very broad clasper (lateral view) with a distinctly angular clasper heel, convex dorsal margin and small clasper hollow. The claspers are parallel to their downcurved apices, but curve slightly outward, towards the proximal half of their dorsal margin. Similar, but less broad claspers are shared by a group of species related to $B$. exhausta Guérin, 1831 .

B. furcillata, B. karkarensis, B. rufula, and $B$. turgida share upward directed, straight and slender claspers, with a distinct crest along the proximal part of the dorsal margin. The claspers in lateral view gradually widen to their base, not forming an angular heel, and slightly diverge towards their 
apices. The apical part of the clasper is straight, with a slightly outcurved clasper hollow. This clasper shape is almost certainly a synapomorphous character for these species.

Shape of aedeagus. - The aedeagi of $\boldsymbol{B}$. brongers$m a i, B$. lorentzi, and $B$. viridis strongly resemble those of most species of the bloetei group: the margin along the aedeagus pore is strongly concave in lateral view (cf. Fig. 12). Especially the aedeagus of $B$. viridis, with its large triangular pore, is almost identical with that of $B$. bloetei De Boer, 1989.

The aedeagi of the remaining four species of the viridis group are broader in lateral view and less concave along the pore, and in this respect they resemble the Bismarck species of the bloetei group. The aedeagus of $B$. rufula is very broad and strongly curved back near its apex, a shape unique for this species (Fig. 38, arrow). B. furcillata, B. karkarensis, and $B$. turgida share a very peculiar aedeagus: very broad and globularly swollen between the lateral lobes. This aedeagus shape is unique for these species.

Conclusion. - Almost all characters discussed above suggest a separation between $B$. brongers$m a i, B$. lorentzi, and $B$. viridis, on the one hand, and $B$. rufula, B. karkarensis, B. turgida, and $B$. furcillata on the other.

\section{Biogeography}

The viridis group is endemic to New Guinea; the species are recorded from Cendrawasih (= Vogelkop Peninsula), the lowland of southern Irian Jaya, the northern moutain ranges, and Karkar Island (Fig. 1).

This distribution area of the viridis group is of composite geological origin. Southern New Guinea formed part of the northern leading edge of the Australian tectonic plate, while the northern part of Cendrawasih and the northern mountain ranges of New Guinea formed the western part of a former island arc, known as the Outer Melanesian Arc (OMA) (Hamilton, 1979; Holloway, 1979; 1984). This OMA is supposed to have been an important

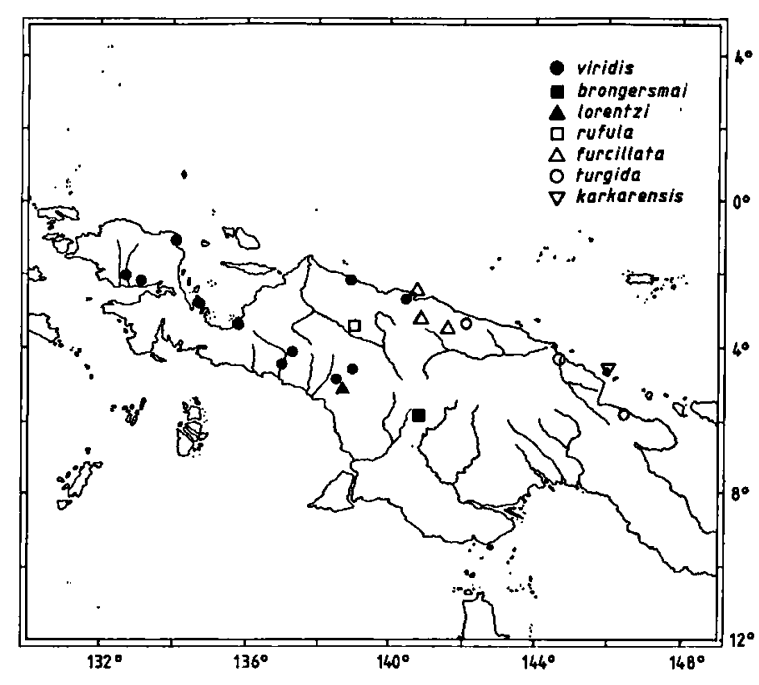

Fig. 1. Distribution of the species of the Baeturia viridis group.

route of dispersal for Asian biota invading the $\mathrm{Pa}$ cific. Though parts of the OMA collided with the Australian continent in the mid Miocene, and formed the island of New Guinea, the subaerial remnants of the OMA can still be recognized (in parts of New Guinea and as West Pacific island groups) as areas of endemism for several groups of organisms (Duffels, 1986; Duffels \& De Boer, 1990).

The two subgroups of the viridis group, as recognized in the previous chapter, are restricted to southern and western New Guinea, and to northern New Guinea, respectively.

The western subgroup consists of $B$. viridis from the northwestern and southwestern New Guinean mainland and part of Cendrawasih, and $B$. brongersmai and $B$. lorentzi, both from southwestern New Guinea. Especially Cendrawashi is an interesting area, both from a geological and a biogeographical point of view. Though at least partly an OMA fragment, it takes a somewhat isolated geological position in relation to other parts of this arc (Hamilton, 1979). This isolation seems to be reflected in the distribution patterns of several groups of cicadas: some groups are endemic to Cendrawasih, while others, widely distributed in other parts of the OMA, bypass this area (Duffels \& De Boer, 1990). However, cicadas of Cendrawasih generally have their nearest relatives on Maluku or 
northern New Guinea (Duffels \& De Boer, 1990). The viridis group indicates a relation of Cendrawasih and the northwestern New Guinean mainland primarily with southern New Guinea and secondarily with other parts of northern New Guinea.

The northern subgroup (B. furcillata, B. karkarensis, $B$. rufula, and $B$. turgida) presents a typical OMA pattern. It is remarkable that the viridis group has no less than five allopatric species in the New Guinean part of the OMA. Several other groups of cicadas have only one or two species, with a much wider distribution, in this area: the Baeturia bloetei group, an OMA group with 18 species, has only two species in northern New Guinea (De Boer, 1989); Baeturia parva Blöte, 1960, of the nasuta group, is distributed from Obi Island over northern New Guinea to the Bismarck Archipelago and Admiralty Islands (De Boer, 1982; unpublished); Diceropyga, an OMA group of more than 20 species, with $D$. bihamata Duffels, 1977, widely distributed in northern New Guinea (Duffels, 1977).

\section{Taxonomy}

Description of the B. viridis group

Body of males either reddish brown, often with brown speckling on head, thorax and predominantly the dorsal parts of the abdomen, or ochraceous to greenish and unspeckled. Abdomen inflated, in speckled species with reddish segmental hind margins and a lateroventral row of dark spots on segments 3-8, in unspeckled species with ochraceous segmental hind margins and dark lateroventral spots restricted to segment 3 and sometimes 4 . Male abdomen 1.2-1.7 times as long as head and thorax together. Male tegmina 1.0-1.2 times as long as body length.

Females of speckled species greyish brown and more densely speckled than males, of unspeckled species light ochraceous or bicoloured; head and thorax green, abdomen ochraceous. Females often shorter than males, but with more robust head and thorax, and longer tegmina. Female abdomen
1.0-1.3 times as long as head and thorax together. Female tegmina 1.2-1.5 times as long as body length.

Head: Postclypeus distinctly protruding beyond vertex lobes, broadly rounded or angularly protruding. Postclypeus 1.4-2.9 times as broad as long. Distance between eyes 1.4-2.1 times as long as postclypeus width. Head only slightly narrower than anterior width of pronotum; pronotal collar 1.2-1.6 times as wide as head. Head 2.1-2.7 times as wide as distance between eyes. Distance between lateral ocelli $0.7-1.4$ times as long as distance between eye and lateral ocellus and 0.9-1.8 times width of frontal ocellus. Eyes $0.6-0.8$ times as wide as distance between eyes.

Thorax: Pronotum with two pairs of deep oblique fissures. Speckling, if present, often most dense between fissures and in medial band. Pronotum 2.0-2.5 times as broad as long. Mesonotum greyish brown, or greenish; in speckled species often with two semicircular dark spots at pronotum margin, darkened lateral bands, and two black spots in front of cruciform elevation. Mesonotum 0.7-0.8 times as long as width of pronotal collar.

Tegmina and wings: Hyaline. Tegmen with 8 , wing with 6 apical areas. Venation ochraceous or greenish, sometimes densely set with setae.

Legs: Fore femur (Fig. 4) with row of three pointed spines, diminishing in length towards tibia.

Tymbal organ: Six or seven parallel sclerotized ridges spanning tymbal from dorsal to ventral margin and a most proximal ridge, hardly separated from proximal tymbal margin, running to about half the tymbal width.

Male genitalia: Pygofer with very stout, strongly bent caudodorsal beak. Dorsal margin of pygofer slightly convex, but concave at base of caudodorsal beak. Dorsal margin of beak straight or slightly convex, but distinctly concave close to apex of beak. Ventral margin of pygofer angularly bent. Ventral margins converging in sharp angle to base of pygofer (Figs. 15, 24). Caudodorsal beak truncate, sometimes pointed, and in two species bifurcate at apex. Lateral lobes of pygofer bear distinctly backwards projecting angular protuberances, with sharp lateral edges. Claspers parallel, not fused at base, and thus not forming a ring around base of 
anal valves. Clasper either gradually broadening towards base, or abruptly broadening dorsally, forming a rectangular corner, here termed "clasper heel" (cf. Figs. 10, 41). Apical part of clasper with sharp-edged ventral incurvation or "clasper hollow." Aedeagus S-curved, with two small lateral lobes at base of curvature.

Female genitalia: Caudodorsal beak sharply pointed or bifurcate at apex. Ovipositor sheaths reaching to, or just beyond, apex of beak.

\section{Key to the males}

1a. Postclypeus oblong and hardly protruding, anterior margin weakly convex (Fig. 2) and not swollen ventrally (Fig. 3), Operculum oval, with convex distal margin (Fig. 7). Claspers parallel, with small clasper hollow, directed downward to apex and broad in lateral view (Fig. 10). Distal margin of pygofer continuously rounded to apex of protuberances on lateral lobes of pygofer (Fig. 5) ........ 2

b. Postclypeus distinctly and angularly protruding, anterior margin strongly convex (Fig. 51) and distinctly swollen ventrally (Fig. 50). Operculum angular, with straight or concave distal margin. Claspers slightly diverging towards apices, with large outward curved clasper hollow, straight, slightly directed upward and slender in lateral view. Distal margin of pygofer ending at half-length of protuberance on lateral lobes of pygofer, or bending rectangularly down to apex of protuberances $\ldots \ldots \ldots \ldots \ldots \ldots \ldots \ldots \ldots \ldots .4$

2a. Protuberances on lateral lobes of pygofer strongly directed mesiad (Fig. 24) .............. B. lorentzi n. sp.

v. Protuberances on lateral loves or pygorer not arrectea mesiad $\ldots \ldots \ldots \ldots \ldots \ldots \ldots \ldots \ldots \ldots \ldots \ldots \ldots$

3a. Body length 21.6-26.5 mm. Protuberance on lateral lobes of pygofer broad, squarish in lateral view. Aedeagus pore wide, almost triangle-shaped (Fig. 14) .............

$\ldots \ldots \ldots \ldots \ldots \ldots \ldots \ldots \ldots$. . viridis Blöte, 1960

b. Body length 18.6-20.0 mm. Protuberances on lateral lobes of pygofer slender in lateral view. Aedeagus pore slender, oval (Fig. 21) ........... B. brongersmai Blöte, 1960

4a. Caudodorsal beak truncate at apex .......... 5

b. Caudodorsal beak bifurcate, ending in two sharp spines 6

5a. Claspers completely concealed within pygofer. Protuberances on lateral lobes of pygofer broad in lateral view and bent mesiad, touching at apices (Fig. 33). Aedeagus not swollen between lateral lobes (Figs. 38, 39) ..........

...................... B. rufula Blöte, 1960

b. Claspers reaching beyond apex of caudodorsal beak. Protuberances on lateral lobes of pygofer slender and directed straightly backwards. Aedeagus distinctly swollen between lateral lobes (Figs. 47, 48) ....... B. karkarensis n. sp. 6a. Body length 19.6-21.0 mm. Distal margin of operculum concave. Distal margin of pygofer almost straight, forming sharp angle with margin of caudodorsal beak. Protuberances on lateral lobes of pygofer straight and slightly directed upward, slender and narrowly rounded at apex; apex of protuberances reaching distinctly beyond distal margin of pygofer ................... turgida n. sp.

b. Body length 14.7-17.3 mm. Distal margin of operculum straight. Distal margin of pygofer concave, gradually bending into margin of caudodorsal beak. Protuberances on lateral lobes of pygofer sharply bending upward at half their length, broadly truncate at apex; apex of protuberance continuous with angular distal corner of lateral pygofer lobe (Fig. 54, arrow) ............. furcillata n. sp.

\section{Description of the species}

\section{Baeturia viridis Blöte, 1960}

(Figs. 1-14)

Baeturia viridis Blöte, 1960: 73, figs. 25-26; Duffels \& Van der Laan, 1985: 255.

Material examined, - Irian: New Guinea (W.): Aiman [possibly Aimau River, northern Cendrawasih], x.1939, R.G. Wind, $1 \sigma^{\circ}$, NCSU; Alkmaar, 4.x.1909, Lorentz, N. Guinea Exped. 1909, 1 ९, ZMA; Alkmaar, ix.1909, Lorentz, 1 ơ, B. exhausta det. A. Jacobi, SMD; Andai, viii.1878, Rozenberg, 1 o , RMNH; Andai, R.F.H. Rippon coll., NMW 1918.93, $1 \sigma^{\circ}$, NMW; Andai, Aej 72, L.M. D'Albertis, $1 \sigma^{\circ}$, BMNH; Archbold Lake, Central Mts., 760 m, 26.xi-3.xii.1961, S. \& L. Quate, 1 o, 7 \& , BPBM; Ifar, Cyclops Mts., 450-500 m, 9.ix.1962, J. Sedlacek, $1 \sigma^{\circ}$, BPBM; Kebar Val., W. of Manokwari, $550 \mathrm{~m}$, 4-31.i.1962, S. \& L. Quate, $3 \circ \sigma^{\circ}, 6$ ㅇ ९, BPBM; same data $1 \%, 1$ \&, ZMA; Malik R., $10 \mathrm{~km}$ E. of Archbold Lake, 1050 m, 25.xi, 3-5.xii.1961, S.\& L. Quate, 1 \& , BPBM; Manokwari, 25.iv.1952, L.D. Brongersma \& W.J. Roosdorp, o holotype, RMNH; Manokwari, $234^{\circ} 5^{\prime} \mathrm{E} / 00^{\circ} 52^{\prime} \mathrm{S}$, 12.iii.1955, L.D. Brongersma c.s., $\odot$ allotype, RMNH; Nabire, S. Geelvink Bay, 0-30 m, 2-9.vii.1962, J.L. Gressitt, 4 o ${ }^{\circ}$, BPBM; Nabire, S. of Geelvink Bay, 11.ix.1962, H. Holtman, 2 ९ ९, BPBM; same data but 13.ix.1962, 1 \&, BPBM; 5-50 m, 25.viii-2.ix.1962, 1 ९, BPBM; $1040 \mathrm{~m}, 7 . x .1962,1$ ९, BPBM; same data but 25.viii-2.ix.1962, J. Sedlacek, 1 ९, BPBM; Noord rivier, ix.1909, Lorentz, 13 o $\circ$, SMD; Sakoemi [Sakaoeni, MacCluer Gulf?], 12.iii.1929, Prince Léopold, 1 \&, KBIN; Tor River (mouth), $4 \mathrm{~km}$ E. of Hol Maffen, 2.vii.1959, T.C. Maa, $1 \sigma^{\circ}$, BPBM; Warior [Wasior], 23/7, 1 o, ZMB; Wondiwoi [Wandiwoi Mts.?], 47D/29, 1 ९, ZMB.

Remarks. - Females can often not be identified to species level. In the SMD 39 Baeturia females from the locality "Noord rivier" were found. These 


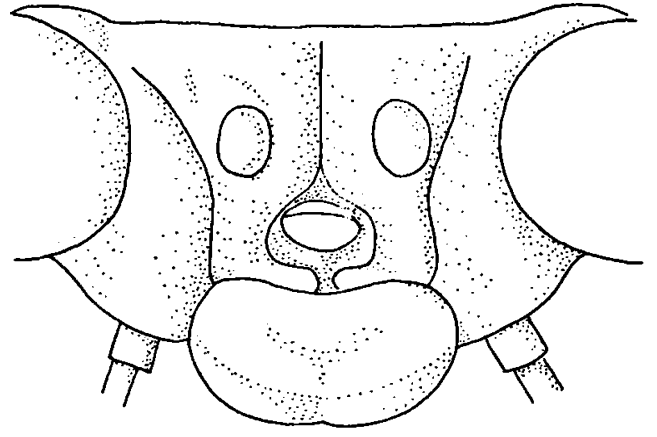

2

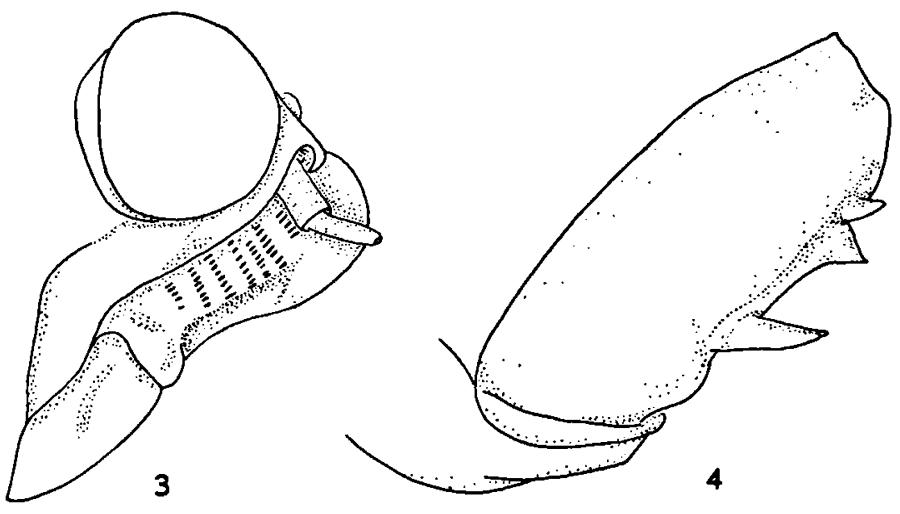

Figs. 2-7. Baeturia viridis Blöte, 1960: 2, head in dorsal view, Nabire; 3, head in lateral view, Nabire; 4, fore femur, Tor River; 5 , pygofer in lateral view, Warior (arrow indicating concavely curved dorsal margin at apex of caudodorsal beak); 6, Caudodorsal beak in dorsal view, Warior; 7 , male operculum, Warior. Lettering: bp = basal part of operculum; $c b=$ caudodorsal beak; $d=$ distal margin of operculum; di = distal margin of pygofer; $\mathrm{dmc}=$ distomedial corner of operculum; do = dorsal margin of pygofer; dp = distal part of operculum; 1 = lateral margin of operculum; $m=$ medial margin of operculum; $p=$ protuberance on lateral lobe of pygofer; ve = ventral margin of pygofer.

specimens either belong to $B$. viridis, or to $B$. lorentzi described below, or to $B$. bloetei De Boer, 1989, the three Baeturia species known from this locality (of the latter species four males from this locality were recently found in the SMD).

$B$. viridis is a large and unspeckled species that can be recognized by the broad and short protuberances on the lateral lobes of the pygofer.

Description. - Body of males strongly varying in colour: some, including holotype, greenish, others ochraceous or red-brown. Females ochraceous brown or bicoloured, with green head and thorax, and ochraceous abdomen. Females on average smaller than males, but with longer tegmina. Tegmina in males 1.0-1.1 times as long as total body length, in females 1.2-1.5 times as long. Male ab- domen 1.3-1.5 times as long as head and thorax together, in females 1.0-1.2 times as long.

Head: Light brown and unspeckled. Head 0.81.0 times as long as distance between eyes. Postclypeus in dorsal view (Fig. 2) broad oblong, 2.0-2.6 times as wide as long. Anterior margin of postclypeus almost straight. Postclypeus not swollen ventrally, anterior margin (lateral view) slightly convex (Fig. 3).

Thorax: Pronotum and mesonotum green or brown, without markings.

Tymbal organ: Six parallel sclerotized ridges spanning tymbal from dorsal to ventral margin, a 7 th ridge ending close to ventral margin, and an 8 th, most proximal ridge, hardly separated from proximal tymbal margin, runs to about half the tymbal width. Seven short intercalary ridges seem 

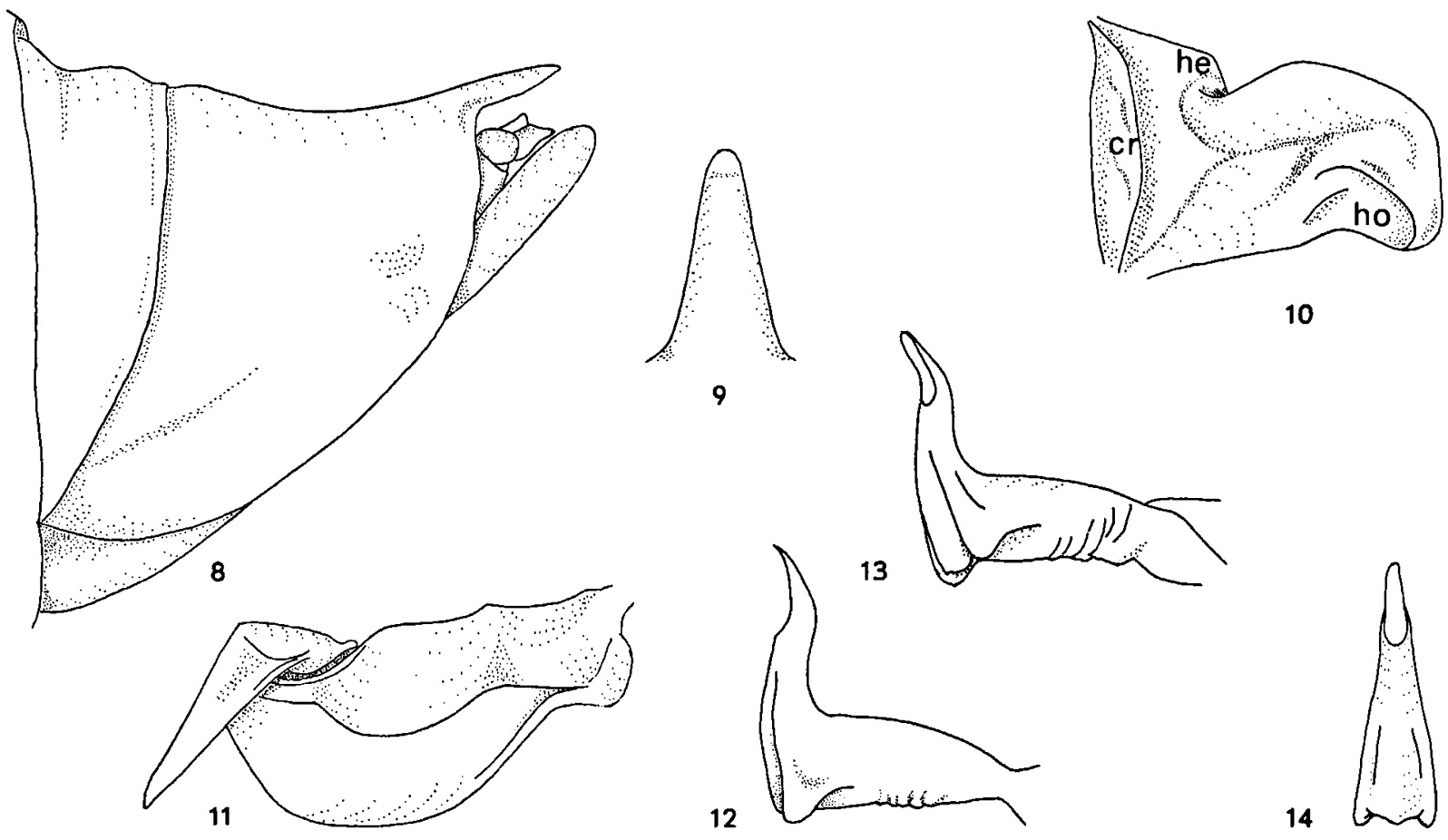

Figs. 8-14. Baeturia viridis Blöte, 1960: 8, female genital segment in lateral view, allotype; 9 , female caudodorsal beak in dorsal view, allotype; 10, clasper, holotype (he = clasper heel; ho = clasper hollow; $\mathrm{cr}=$ crest across base of clasper); 11, female operculum, allotype; 12, aedeagus in lateral view, Tor River; 13, aedeagus from aslant, Tor River; 14, aedeagus from behind, Tor River.

to form a lateral band across tymbal.

Opercula: Male operculum (Fig. 7) almost flat against body and covering most of tymbal cavity in ventral view. Distal part of operculum almost oval, lateral margin straight, angularly bent into long and slightly convex distal margin. Medial margin straight. Distomedial corner almost rectangular. Meracanthus reaching to about $2 / 3$ operculum length. Female operculum (Fig. 11) larger than usual in Baeturia and curved towards abdomen along distal margin. Distal part resembling that of $B$. bloetei, but distinctly broader, more rounded and slightly trapezoid-shaped. Lateral margin short and straight, and directed mesiad. Distolateral corner broadly rounded. Distal margin straight, forming a wide angle with straight medial margin.

Legs: Fore femur (Fig. 4) with row of three pointed spines, diminishing in length towards tibia.

Abdomen: Male abdomen uniformly ochraceous or red-brown. Often one lateroventral spot on segment 3 and a row of vague and unpigmented patches on segments 4-7. Female abdomen ochraceous brown. Female caudodorsal beak (Fig. 9) long, slender and triangular, narrowly rounded or pointed at apex. Ovipositor sheaths reaching to apex of caudodorsal beak (Fig. 8).

Male genitalia: Pygofer in lateral view illustrated (Fig. 5). Distal margin of pygofer continuously rounded from apex of lateral protuberance to apex of caudodorsal beak. Caudodorsal beak in dorsal view (Fig. 6) almost truncate at apex, but pointed in two specimens from Nabire. Lateral lobes of pygofer with short, but distinctly backwards projecting protuberances. These protuberances, very broad in lateral view, are laterally and dorsally flattened, and form a sharp lateral edge. This edge bends angularly upwards at half-length. Claspers very broad in lateral view (Fig. 10), often far protruding distally, reaching beyond apex of caudodorsal beak; in one specimen pulled back into pygofer, as in $B$. lorentzi n. sp. Lateral crest on clasper base clearly visible in most specimens, due 
to prominent position of clasper. Clasper base with distinct rectangular clasper heel. Dorsal margin of clasper bent upwards from clasper base and angularly rounded, to almost semi-circular, towards clasper apex. Clasper curving laterad towards proximal part of dorsal margin. Apical part of clasper, slightly downwards curved, with small ventral hollow. Aedeagus in lateral view stout and strongly Scurved, with bluntly rounded lateral lobes, strongly concave along margin of pore (Figs. 12-13). Aedeagus from behind (Fig. 14) convex between lateral lobes. Aedeagus pore broad, apically pointed, and almost triangle-shaped.

Measurements. - Body length $\sigma^{\prime}:$ 21.6-26.5 mm (mean 23.9 $\mathrm{mm} \pm 1.4$ ), $\%: 17.4-22.8 \mathrm{~mm}$ (mean $20.8 \mathrm{~mm} \pm 1.7$ ); tegmen length $\sigma^{\prime}: 23.0-28.1 \mathrm{~mm}$ (mean $24.5 \mathrm{~mm} \pm 1.4$ ), $\$: 24.3-32.0$ $\mathrm{mm}$ (mean $28.3 \mathrm{~mm} \pm 1.8$ ); pronotum length ơ : $2.8-3.4 \mathrm{~mm}$ (mean $3.1 \mathrm{~mm}$ ), $९: 2.9-3.7 \mathrm{~mm}$ (mean $3.3 \mathrm{~mm}$ ); mesonotum length $\sigma^{\prime}:$ 4.7-5.5 $\mathrm{mm}$ (mean $5.0 \mathrm{~mm}$ ), $९: 4.5-5.9 \mathrm{~mm}$ (mean $5.3 \mathrm{~mm}$ ); head length $\sigma: 1.6-2.3 \mathrm{~mm}$ (mean $1.9 \mathrm{~mm}$ ), $\odot$ : 1.6-2.2 mm (mean $1.9 \mathrm{~mm}$ ); head width $\sigma^{\circ}: 4.7-5.6 \mathrm{~mm}$ (mean $5.1 \mathrm{~mm}$ ), $९: 4.5-5.6 \mathrm{~mm}$ (mean $5.2 \mathrm{~mm}$ ); width of pronotal collar $\sigma^{\circ}:$ 6.3-7.5 mm (mean $6.9 \mathrm{~mm}$ ), $९: 6.5-8.3 \mathrm{~mm}$ (mean 7.6 $\mathrm{mm})$.

Distribution (Fig. 1). - Northwestern and southwestern New Guinea, including the northeastern part of Cendrawasih.

Baeturia brongersmai Blöte, 1960

(Figs. 1, 15-23)

Baeturia brongersmai Blöte, 1960: 71-72, figs. 20-21; Duffels \& Van der Laan, 1985: 252.

Material examined: Irian: New Guinea (W.): Tanah Merah, 17 m, 25-29.ix.1959, Neth. New Guinea Exped. 1959, 1 o paratype, 3 ९ paratypes, RMNH; Tanah Merah, Boven Digoel, S. Neth. New Guinea, 17 m, 9.iv.1955, L.D. Brongersma c.s., O holotype, 1 \% paratype, RMNH; same data but 15.iv.1955, $\uparrow$ allotype, RMNH; Tanah Merah, 15.iv.1959, C.B. Nicolas, Neth. New Guinea Exped., 2 ९ ९, RMNH.

Remarks. - Of $B$. brongersmai only the type series from Tanah Merah is known, though two females from the same locality probably belong to this species. The species is very similar to $B$. viridis, but considerably smaller. The protuberances on the lateral pygofer lobes are narrowly rounded apical- ly, and slightly longer and more slender than in $\boldsymbol{B}$. viridis. Furthermore, $B$. brongersmai has a narrower, almost oval aedeagus pore.

Description. - Holotype yellowish brown, male paratype olive green, females bicoloured, with green head and thorax, and ochraceous abdomen. Males and females unspeckled. Females on average slightly smaller than males, but with more robust head and thorax and longer tegmina. Tegmina in males 1.0-1.1 times as long as body length, in females 1.2-1.3 times as long. Male abdomen 1.3-1.6 times as long as head and thorax together, in females 1.1-1.3 times as long.

Head: Ochraceous or green and unspeckled. Head 0.8-0.9 times as long as distance between eyes. Postclypeus in dorsal view broad and oblong as in B. viridis (cf. Fig. 2) and 1.8-2.9 times as wide as long. Anterior margin of postclypeus broadly convex. Postclypeus not swollen ventrally, anterior margin (lateral view) slightly convex.

Tymbal organ: Six parallel sclerotized ridges spanning tymbal from dorsal to ventral margin, a 7 th ridge ending close to ventral margin, and an 8th, most proximal ridge, hardly separated from proximal tymbal margin, runs to about half the tymbal width. Seven short intercalary ridges seem to form a lateral band across tymbal.

Opercula: Male operculum (Fig. 19) as in B. viridis, but slightly shorter, only just reaching margin of abdominal segment 2. Operculum almost flat against body and covering most of tymbal cavity in ventral view. Distal part of operculum almost oval, lateral margin straight, angularly bent into long and slightly convex distal margin. Medial margin straight. Distomedial corner almost rectangular. Meracanthus reaching to about 3/4 of operculum length. Female operculum (Fig. 22) more rounded than in $B$. viridis, broad sickle-shaped. Lateral margin short and straight, directed mesiad, distolateral corner broadly rounded. Distal margin convex and medial margin almost straight. Distomedial corner rounded.

Abdomen: Male abdomen yellowish brown in holotype, olive green in paratype. Two distinct black lateroventral spots on segments 3 and 4 , and a row of vague and unpigmented patches on suc- 

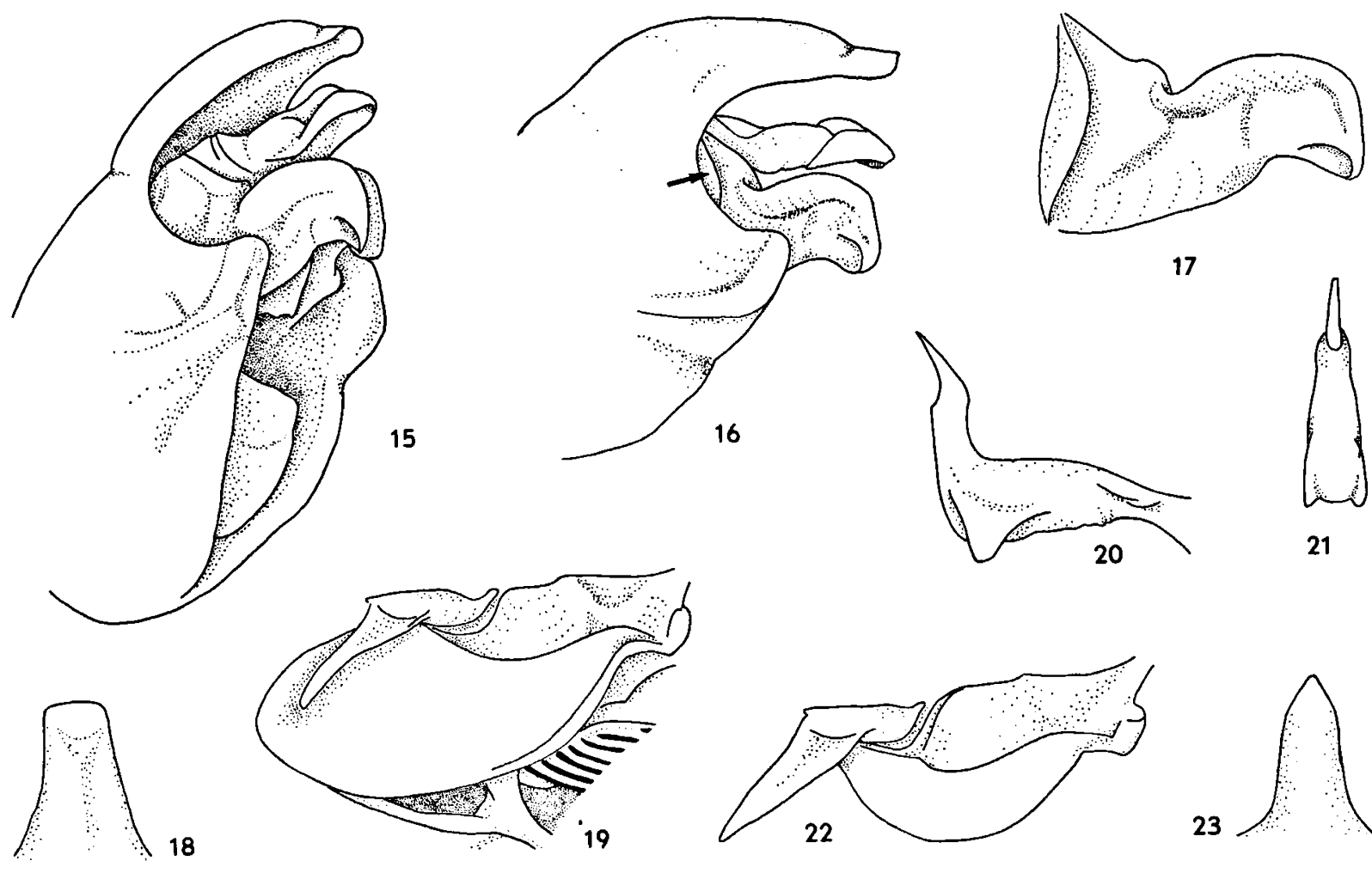

17
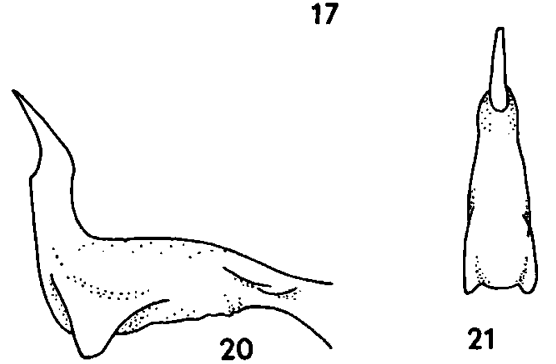

21

Figs. 15-23. Baeturia brongersmai Blöte, 1960: 15, pygofer from aslant, holotype; 16, pygofer in lateral view, holotype (arrow indicating lateral crest of clasper base); 17, clasper, holotype; 18, caudodorsal beak in dorsal view, holotype; 19, male operculum, paratype; 20 , aedeagus in lateral view, paratype; 21 , aedeagus from behind, paratype; 22, female operculum, paratype; 23, female caudodorsal beak in dorsal view, paratype.

ceeding segments. Segmental margins ochraceousgreen. Female abdomen ochraceous, slightly greenish tinged and unspeckled. Female caudodorsal beak in dorsal view (Fig. 23) narrowly rounded or pointed at apex.

Male genitalia: Pygofer in lateral view closely resembling that of $B$. viridis. Distal margin of pygofer continuously rounded from apex of lateral protuberance to apex of caudodorsal beak (Figs. 15-16). Caudodorsal beak in dorsal view (Fig. 18) truncate at apex. Lateral lobes of pygofer as in $\boldsymbol{B}$. viridis but with more slender and distinctly backwards projecting protuberances. These protuberances are laterally and dorsally flattened, and form a sharp lateral edge, that angularly bends upwards at half-length. Protuberances narrowly rounded at apex. Claspers as in $B$. viridis, very broad in lateral view (Fig. 17) and reaching beyond apex of caudodorsal beak. Lateral crest across clasper base clear- ly visible, because of prominent position of clasper (Fig. 16, arrow). Clasper base with distinct angular clasper heel. Dorsal margin of clasper bent upwards from clasper base, and angularly rounded, to almost semicircular, towards clasper apex. Clasper curved laterad towards proximal part of its dorsal margin. Apical part of clasper slightly curved downwards, with small ventral hollow. Aedeagus in lateral view (Fig. 20) strongly S-curved, with bluntly rounded lateral lobes, strongly concave along margin of pore. Aedeagus from behind (Fig. 21) convex between lateral lobes. Aedeagus pore narrow, almost oval, and apically truncate.

Measurements. - Body length $\sigma^{\circ}: 18.6$ and $20.0 \mathrm{~mm}$, $Q$ : 16.3-19.3 mm (mean $17.9 \mathrm{~mm} \pm 1.1$ ); tegmen length $\sigma^{\circ}: 19.6$ and $20.0 \mathrm{~mm}$, $\mathrm{Q}: 20.8-24.5 \mathrm{~mm}$ (mean $22.6 \mathrm{~mm} \pm 1.2$ ); pronotum length $\sigma: 2.4$ and $2.6 \mathrm{~mm}, \$: 2.6-3.0 \mathrm{~mm}$ (mean $2.8 \mathrm{~mm}$ ); mesonotum length $\sigma: 3.7$ and $3.9 \mathrm{~mm}, \&: 3.7-4.7 \mathrm{~mm}$ (mean $4.2 \mathrm{~mm}$ ); head length $\sigma: 1.7 \mathrm{~mm}$ both, $\odot: 1.5-1.9 \mathrm{~mm}$ (mean 
$1.8 \mathrm{~mm}$ ); head width $\sigma: 4.3 \mathrm{~mm}$ both, $९: 4.4-5.0 \mathrm{~mm}$ (mean $4.7 \mathrm{~mm}$ ); width of pronotal collar $\sigma: 5.5$ and $5.7 \mathrm{~mm}$, $९$ : $5.9-6.8 \mathrm{~mm}$ (mean $6.5 \mathrm{~mm}$ ).

Distribution (Fig. 1). - All available material comes from Tanah Merah, Upper Digul area, southern Irian Jaya.

Baeturia lorentzi $\mathrm{n} . \mathrm{sp}$.

(Figs. 1, 24-32)

Material examined. - Holotype: " $Z$ Nieuw Guinea Exp, 1.xi.09, Noord rivier, Lorentz leg" (written), O’, ZMA. Paratypes: same data as holotype, but printed label, 6.ix.1909, 1 \&, ZMA; Noord rivier (Lorentz River), 17.v.1906, Nieuw Guinea Exped. 1906, 2 \& , ZMA. Other material: Bivak eiland, 17.ix.1912, 3e S. New Guinea Exped. 1912-13, 1 \%, ZMA; Bivak eil. 9, 1912-13, Versteeg, 5 ९ ९, ZMA.

Remarks. - Of B. lorentzi only one male is known. A number of females, from the same area, presumably belong to this species, though they could not be separated on morphological grounds from females of $B$. bloetei and $B$. viridis. The male is easily recognized by its long, inwards curved protuberances on the lateral lobes of the pygofer. Females have very large and curved opercula and a sharply pointed caudodorsal beak.

Description. - Body of male light greyish brown, discoloured by storage in alcohol, and unspeckled. Females ochraceous or grey-brown. Male abdomen somewhat shriveled. Females as large as male, but with longer tegmina. Male tegmen 1.2 times as long as total body length, in females 1.3-1.4 times as long. Male abdomen 1.3 times as long as head and thorax together, in females 1.0-1.2 times as long.

Head: Light brown and unspeckled. Head 0.8-0.9 times as long as distance between eyes. Postclypeus in dorsal view broad and oblong (cf. Fig. 2), 1.6-2.2 times as wide as long. Anterior margin of postclypeus almost straight. Postclypeus not swollen ventrally, anterior margin (lateral view) slightly convex.

Thorax: Pronotum and mesonotum grey-brown or ochraceous, without markings.

Tymbal organ: Six parallel sclerotized ridges spanning tymbal from dorsal to ventral margin, a 7 th ridge ending close to ventral margin and an 8 th, most proximal ridge, hardly separated from proximal tymbal margin, runs to about half the tymbal width. Seven short intercalary ridges seem to form a lateral band across tymbal.

Opercula: Male operculum (Fig. 30) almost flat against body and covering most of tymbal cavity in ventral view. Distal part of operculum angularly oval-shaped, lateral margin straight, angularly bent into long and almost straight distal margin. Distomedial corner broadly rounded. Medial margin straight, rectangularly bent at medial corner. Meracanthus almost reaching distomedial edge of operculum. Female operculum (Fig. 31) closely resembling that of $B$. bloetei (cf. De Boer, 1989). Lateral margin of distal part long and straight, rising abruptly, almost rectangularly, from the crest around distolateral corner of basal part, and running almost parallel to body axis. Distolateral corner broadly rounded. Distomedial corner angular. Distal margin almost straight, angularly bent at half-length. Operculum strongly curved to abdomen at distolateral edge.

Abdomen: Male abdomen badly preserved and shriveled. Lateroventral row of black spots very distinct on segments 3-5, but absent on succeeding segments. Female abdomen ochraceous brown. Female caudodorsal beak in dorsal view (Fig. 32) triangular and sharply pointed at apex. Ovipositor sheaths reaching just beyond apex of caudodorsal beak.

Male genitalia: Pygofer in lateral view illustrated (Fig. 25). Distal margin of pygofer in lateral view less concave than in foregoing species, but continuously curved from apex of lateral protuberance to straight margin of caudodorsal beak. Caudodorsal beak in dorsal view (Fig. 29) very stout and rounded at apex. Lateral lobes of pygofer strongly curved inwards and provided with distinctly backwards projecting protuberances. These protuberances are laterally and dorsally flattened, forming a sharp lateral edge, angularly bent upwards at half-length. Protuberances curved mesiad, their apices reaching to below claspers (Fig. 24). Claspers retracted in pygofer, only partly visible in lateral view (Figs. $25-26$ ), reaching just beyond apices of lateral pro- 

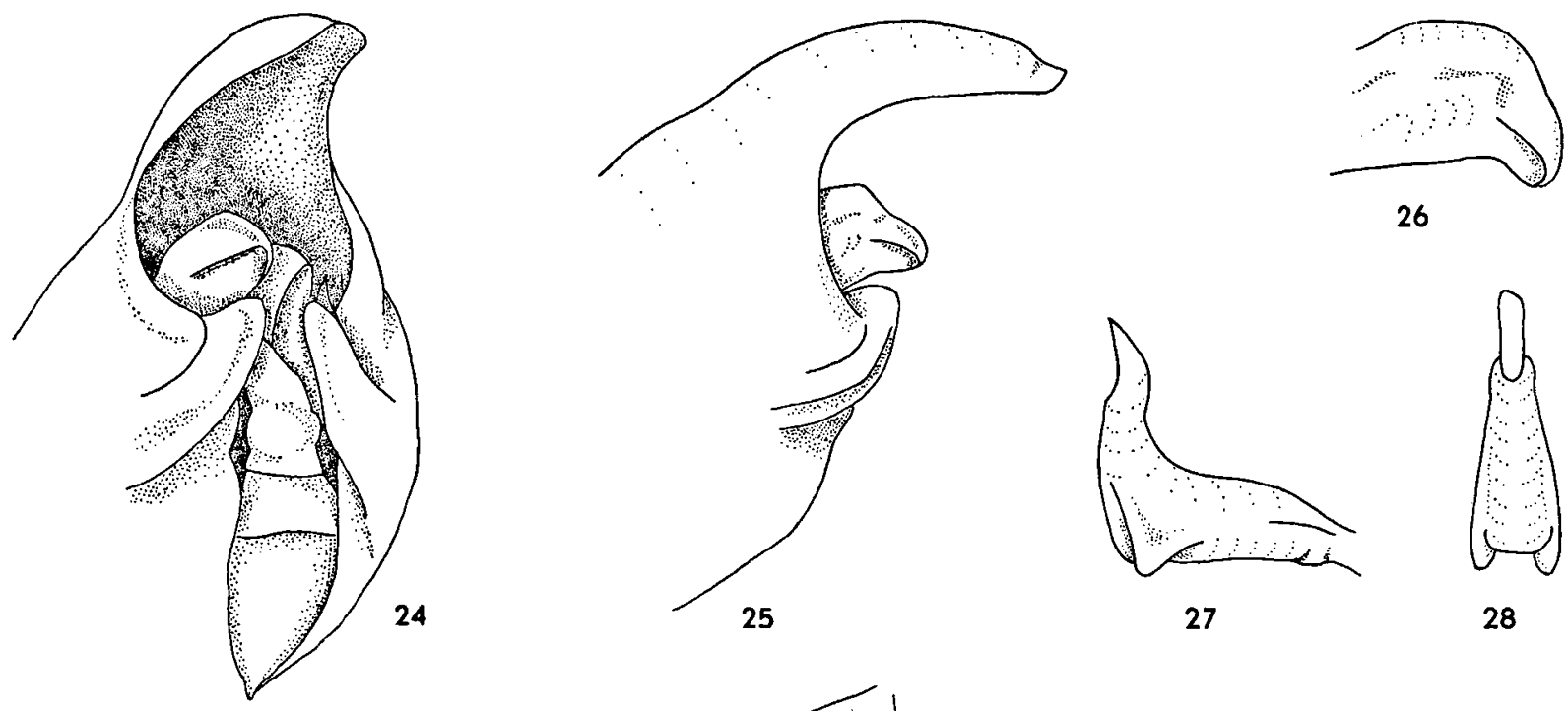

26

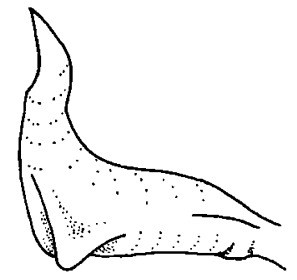

27

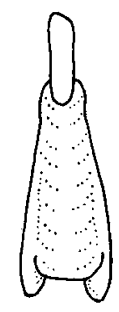

28
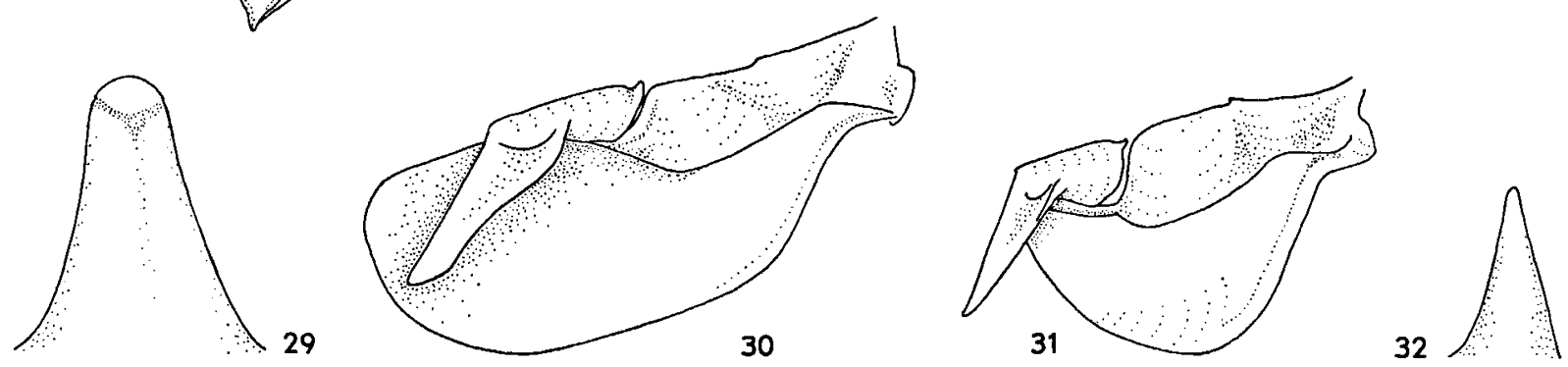

Figs. 24-32. Baeturia lorentzi n. sp.: 24, pygofer from aslant; 25, pygofer in lateral view; 26, clasper; 27, aedeagus in lateral view; 28, aedeagus from behind; 29 , male caudodorsal beak in dorsal view; 30, male operculum; 31, female operculum, paratype; 32, female caudodorsal beak in dorsal view, paratype.

tuberances. A comparable position of the claspers was found in some specimens of $B$. viridis. Clasper closely resembling that of both foregoing species, very broad in lateral view, with convex dorsal margin, slightly concave just before reaching clasper apex. Apical part of clasper, slightly downwards curved, with small ventral hollow. Base of clasper not visible in lateral view. Aedeagus in lateral view (Fig. 27) closely resembling that of foregoing species, strongly S-curved and strongly concave along margin of pore. Aedeagus from behind (Fig. 28) almost straight between lateral lobes. Aedeagus pore broad and oval-shaped.

Measurements. - Body length $\sigma^{\prime}: 19.5 \mathrm{~mm}, \propto: 18.4-22.6 \mathrm{~mm}$ (mean $20.5 \mathrm{~mm} \pm 1.0$ ); tegmen length $\sigma: 24.0 \mathrm{~mm}$, \&: 26.0-28.0 mm (mean $26.5 \mathrm{~mm} \pm 1.0$ ); pronotum length $\sigma: 2.7$ $\mathrm{mm}$, $:$ : 2.7-3.2 mm (mean $2.9 \mathrm{~mm}$ ); mesonotum length $\sigma: 4.2$ $\mathrm{mm}$, : : 4.4-5.7 mm (mean $5.0 \mathrm{~mm}$ ); head length $\sigma: 1.6 \mathrm{~mm}$, ९: $1.5-1.9 \mathrm{~mm}$ (mean $1.8 \mathrm{~mm}$ ); head width $\sigma^{\circ}: 4.8 \mathrm{~mm}$, \%:
4.4-5.3 mm (mean $4.7 \mathrm{~mm}$ ); width of pronotal collar $\sigma: 6.6$ $\mathrm{mm}$, ᄋ : 6.6-7.6 mm (mean $6.9 \mathrm{~mm}$ ).

Distribution (Fig. 1). - One male from the Lorentz River, South Irian Jaya. Some females from several localities along this river presumably belong to the species (see remark preceding the description of $B$. viridis).

Etymology. - This species is named in honour of Dr. H.A. Lorentz, leader of two expeditions to southern New Guinea (1907 and 1912-13), who collected the holotype at the Noord rivier, later Lorentz River.

Baeturia rufula Blöte, 1960

(Figs. 1, 33-39)

Baeturia rufula Blöte, 1960: 69-71, figs. 17-18; Duffels \& Van der Laan, 1985: 254. 


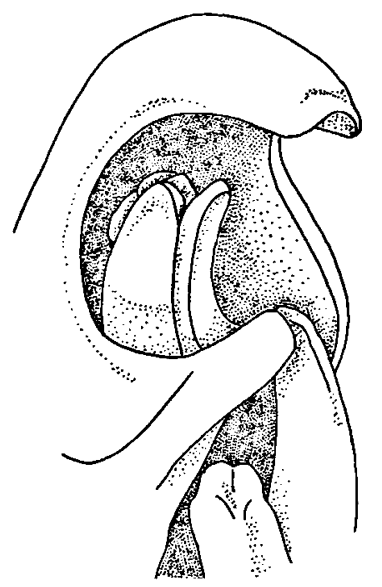

33

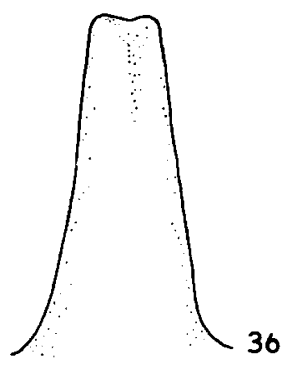

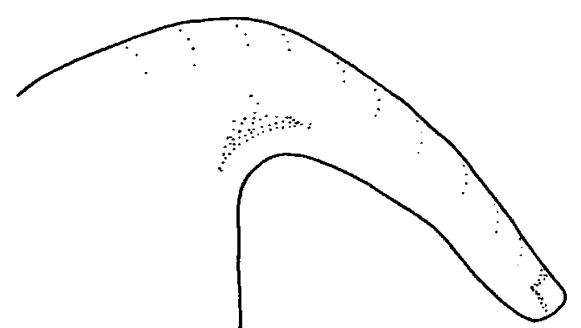

34

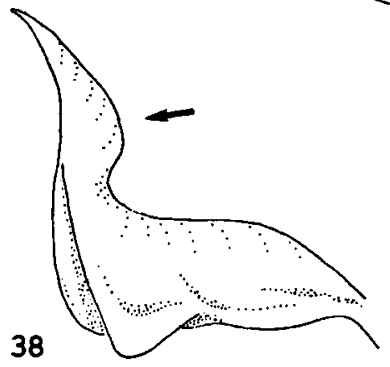

39
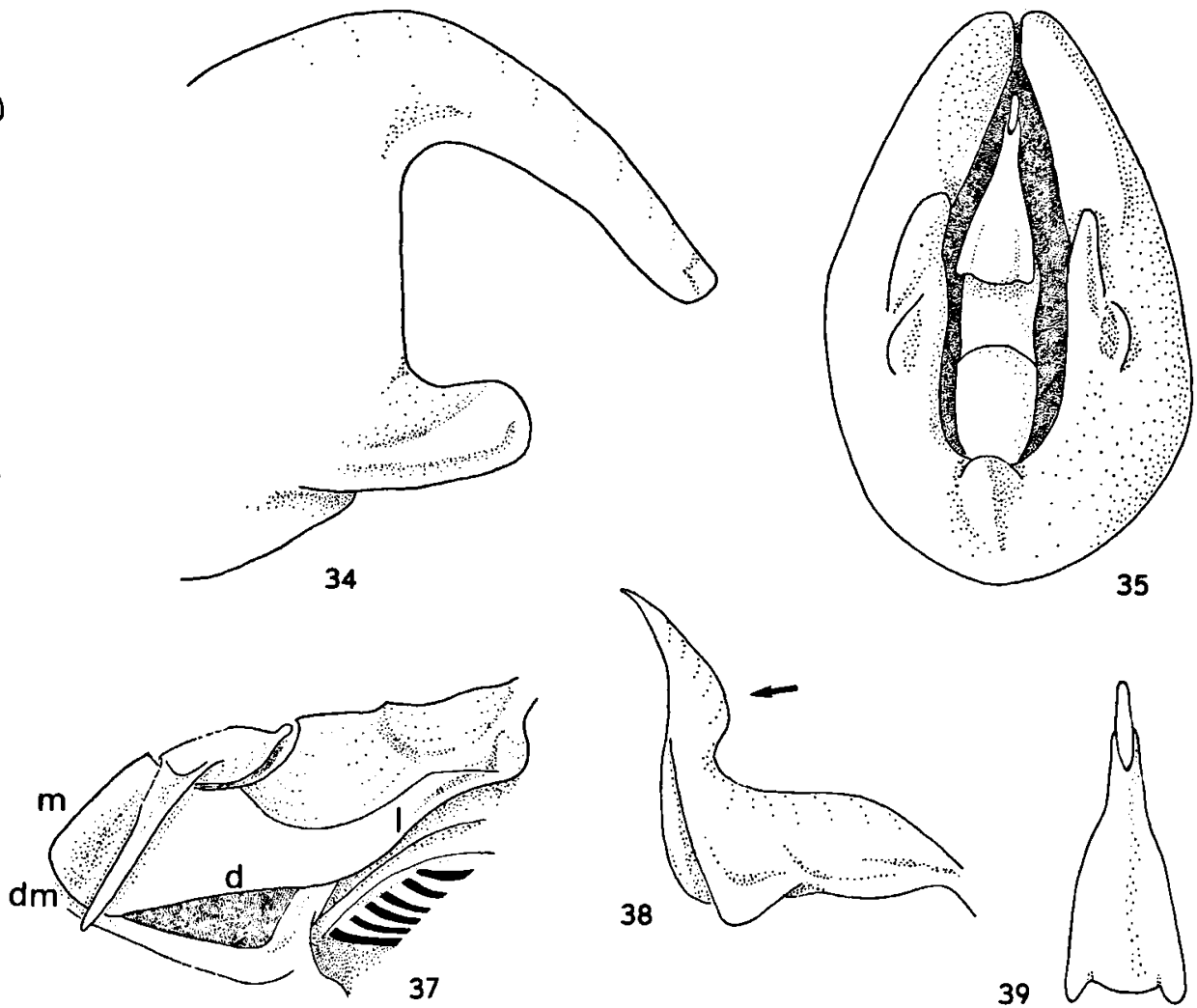

Fig. 33-39. Baeturia rufula Blöte, 1960: 33, pygofer from aslant; 34, pygofer in lateral view; 35, pygofer from below; 36, caudodorsal beak in dorsal view; 37 , operculum ( $d=$ distal margin; $\mathrm{dm}=$ distomedial margin; $1=$ lateral margin; $\mathrm{m}=$ medial margin); 38 , aedeagus in lateral view (arrow indicating strongly recurving apical part); 39, aedeagus from behind.

Material examined. - Irian: New Guinea (W.): Araucaria camp, 800 m, 30.iii.1939, Neth. Ind. American New Guinea Exped., L.J. Toxopeus, of holotype, RMNH.

Remarks. - Of B. rufula only the holotype is known. The species is easily recognized by the elongate protuberances on the lateral lobes of the pygofer, which curve mesiad and touch at their apices, and by its small claspers, that are not visible in lateral view.

Description. - Body reddish brown and unspeckled. Abdomen 1.6 times as long as head and thorax together. Tegmina 1.1 times as long as total body length.

Head: Red-brown, unspeckled. Head 1.1 times as long as distance between eyes. Postclypeus in dorsal view triangularly protruding (cf. Fig. 51), indented in dorsal surface and 2.1 times as wide as long. Postclypeus slightly swollen ventrally, anterior margin (lateral view) angularly rounded.

Thorax: Pronotum unspeckled, ochraceous-red, more intensely red in medial band and on pronotal collar. Mesonotum unspeckled, proximal part greybrown; distal part, cruciform elevation and lateral bands reddish.

Tymbal organ: Six parallel sclerotized ridges spanning tymbal from dorsal to ventral margin, a 7th ridge ending close to ventral margin and an 8th, most proximal ridge, hardly separated from proximal tymbal margin, runs to about half the tymbal width. Seven short intercalary ridges very vaguely visible.

Operculum (Fig. 37): Distal part of operculum very short, angular, almost oblong and erect. Operculum not covering tymbal cavity in ventral view. Short lateral margin bending into concave distal margin. Distomedial margin short and straight, 
forming a rectangular corner with straight medial margin. Meracanthus reaching just beyond operculum.

Abdomen: Reddish brown, inflated, and unspeckled. Middorsal band slightly darkened, posterior margins of segments $3-8$ orange-red. Lateroventral row of dark spots on segments 3-6 slightly darkened but clearly visible.

Male genitalia: Pygofer in lateral view illustrated (Fig. 34) with very long and sharply downwards bent caudodorsal beak. Distal margin of pygofer straight, making a sharp, though rounded, angle with almost straight margin of caudodorsal beak, and concavely bent into straight margin of upwards directed protuberances. Caudodorsal beak in dorsal view (Fig. 36) truncate at apex. Lateral lobes of pygofer with straight, but slightly upwards directed stout protuberances. These protuberances are very long, almost oblong in lateral view, bending strongly mesiad and touching each other at blunt apices (Fig. 33). Pygofer opening between ventral margins very narrow (Fig. 35). Ventral margins concave towards base, ending in small rounded basal protrusion. Claspers very short and erect, completely hidden in pygofer and not visible in lateral view. Apical part of clasper very slender and straight, with large outwards curved clasper hollow (Fig. 33). Claspers slightly diverging to apices. Aedeagus projecting from pygofer, ventrally of lateral protuberances, which could be its natural position since the aedeagus can not be folded back, or pass between the protuberances. Aedeagus very broad in lateral view (Fig. 38) with dorsal margin of apical part strongly recurving, before reaching apical curvature (see arrow). Aedeagus slightly concave along margin of pore. Lateral lobes broadly rounded. Aedeagus from behind (Fig. 39) with weak medial ridge and long, slender pore. Aedeagus slightly convex between lateral lobes.

Measurements. - Body length $22.0 \mathrm{~mm}$; tegmen length 24.9 $\mathrm{mm}$; pronotum length $2.6 \mathrm{~mm}$; mesonotum length $4.4 \mathrm{~mm}$; head length $1.9 \mathrm{~mm}$; head width $4.5 \mathrm{~mm}$; width of pronotal collar 5.7 $\mathrm{mm}$.

Distribution (Fig. 1). - The male holotype, the only specimen known, comes from Araucaria camp, centrally in northern Irian Jaya.
Baeturia turgida $\mathrm{n} . \mathrm{sp}$.

(Figs. 1, 40-49)

Material examined. - Holotype: "New Guinea NE/Finisterre Range/Saidor Sibog vill./v.27-vi-5-1958" [print]; "W.W. Brandt/collector/BISHOP" [print], ${ }^{\circ}$, BPBM. Paratypes: New Guinea (N.E.): same data as holotype, 1 \&, BPBM; Sepen vill., Madang Prov., 29.iv \& 30.v.1988, J. v. Stalle, $2 \sigma^{\circ} \sigma^{\circ}$, KBIN; Sugoitei vill., Torricelli Mts., 900 m, 10-28.ii.1959, W.W. Brandt, $1 \sigma$, ZMA.

Remarks. - B. turgida closely resembles $B$. rufula in shape of pygofer and male operculum, but $B$. turgida is smaller and has a swollen aedeagus. Males and female have a sharply bifurcate caudodorsal beak. $B$. turgida shares these characters with B. furcillata, described next.

Description. - Body of males very light reddish brown, slightly brown speckled on head and pronotum. Female darker brown, more heavily brown speckled. Female about as long as males, but with more robust head and thorax and distinctly longer tegmina. Tegmina in males 1.0-1.1 times as long as total body length, in female 1.3 times as long. Male abdomen 1.6-1.7 times as long as head and thorax together, in female 1.2 times as long.

Head: Red-brown, brown speckled all over. Head 1.0-1.2 times as long as distance between eyes. Postclypeus in dorsal view triangularly protruding (cf. Fig. 51), with convex anterior margin, 1.4-2.0 times as wide as long. Postclypeus distinctly swollen, with broadly rounded anterior margin (lateral view). Head very narrow, with ocelli close together. Distance between lateral ocelli 0.9-1.1 times as wide as frontal ocellus; in other species of the viridis group varying between $1.1-1.9$ times as wide.

Thorax: Pronotum ochraceous, red tinged in broad medial band between medial fissures and on pronotal collar. Brown speckling almost exclusively in these red areas, and most dense in medial band. Mesonotum grey-brown, unspeckled though brown stained, tinged with red on cruciform elevation, in lateral bands, and in triangular area in front of elevation. Two distinct black spots in front of cruciform elevation.

Tymbal organs: Six parallel sclerotized ridges 


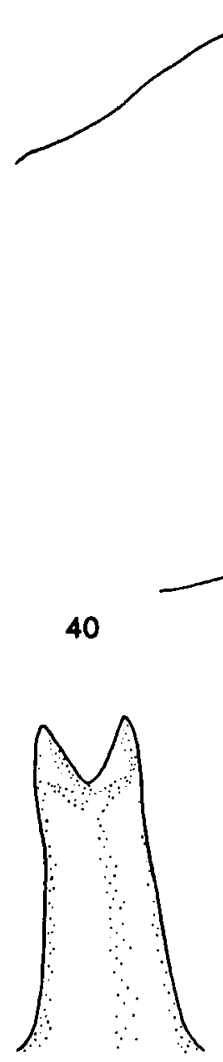

45

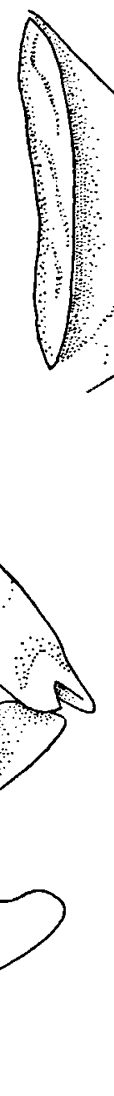

46

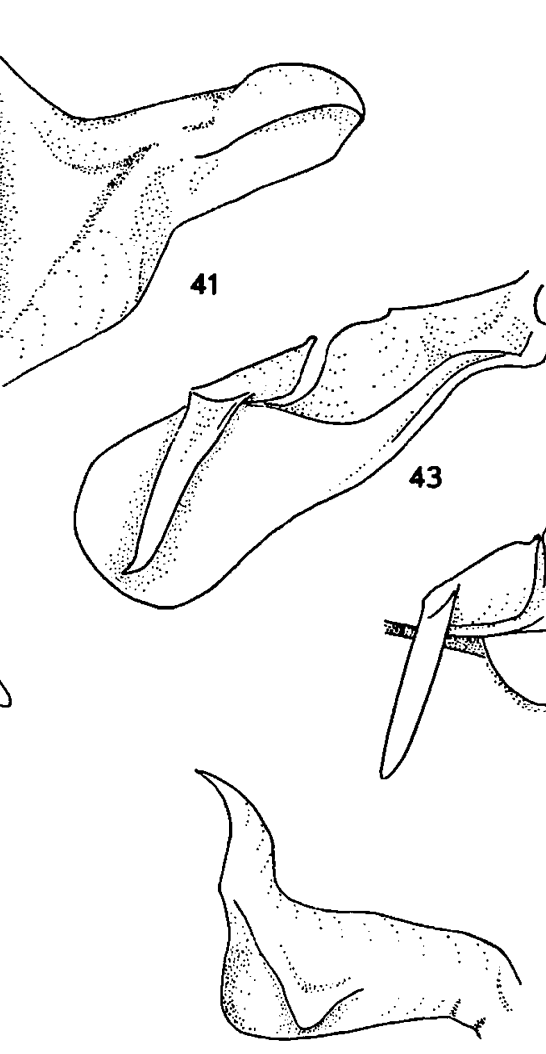

47

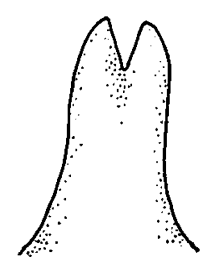

42

Figs. 40-48. Baeturia turgida n. sp.: 40, pygofer in lateral view, holotype; 41 , clasper, holotype; 42, female caudodorsal beak in dorsal view; 43, male operculum, holotype; 44, female operculum; 45, male caudodorsal beak in dorsal view, holotype; 46, pygofer from aslant, holotype; 47 , aedeagus in lateral view, holotype; 48 , aedeagus from behind, holotype.

spanning the tymbal, from dorsal to ventral margin and a partly developed 7 th ridge, along proximal tymbal margin, reaching from dorsal margin to about half the tymbal width. Six short intercalary ridges are vaguely discerned. Tymbal bright red between ridges and at margins.

Opercula: Male operculum (Fig. 43) very short, slender, angular and almost oblong, closely resembling that of $B$. rufula, with a similarly concave distal margin, though longer medially. Distomedial margin slightly convex, broadly rounded into straight medial margin. Distomedial edge of operculum reaches proximal margin of abdominal segment 2. Operculum slightly erect, but curved to body at distal margin. Meracanthus not reaching beyond margin of operculum. Female operculum (Fig. 44) smaller than in foregoing species. Distal part of operculum sickle-shaped and erect.

Abdomen: Male abdomen reddish brown and unspeckled, but with two parallel rows of darkened dorsal spots forming dorsal bands. Segmental hind margins red. A very distinct lateroventral row of dark spots on segments 3-8. Female abdomen greyish brown, dorsal parts reddish, speckled all over. Segmental hind margins red. A distinct lateroventral row of dark spots on segments 3-7. Female caudodorsal beak (Fig. 42) bifurcate as in male, ending in two sharp spines. Ovipositor sheaths reaching beyond apex of caudodorsal beak (Fig. 49).

Male genitalia: Pygofer in lateral view illustrated (Fig. 40), closely resembling that of $B$. rufula, with long and almost straight, sharply downwards curved, caudodorsal beak. Distal margin of pygofer 
straight, making a sharp angle with almost straight margin of caudodorsal beak, and concavely bent into straight margin of upwards directed protuberances. Caudodorsal beak in dorsal view (Fig. 45) very long and bifurcate, ending in two sharp spines. Lateral lobes of pygofer with slender and straight, but slightly upwards directed protuberances, more slender than in $B$. rufula and not curved mesiad, but sometimes sharply curved upwards near apex. Protuberances dorsally and ventrally flattened, forming a sharp, straight lateral edge. Clasper (Fig. 41) very straight and erect, standing almost vertically in pygofer, though more directed backwards in one specimen from Sepen Village. Clasper in very prominent position, lateral crest on clasper base clearly visible. Apical part of clasper slender, with large outwards curved ventral hollow, and weak crest along proximal half of dorsal margin. Clasper gradually broadening towards base, thus not forming angular clasper heel. Claspers slightly diverging at apices (Fig. 46). Aedeagus in lateral view (Fig. 47) very stout, globularly swollen between, and distally of, lateral lobes and strongly concave along margin of pore, but more gradually concave than in $B$. brongersmai, $B$. lorentzi, and $B$. viridis. Aedeagus from behind (Fig. 48) very broad and convex between lateral lobes. Aedeagus pore long, narrow and oval, truncate at apex.

Measurements. - Body length $\sigma^{\prime}:$ 19.6-21.0 mm (mean $20.4 \mathrm{~mm}$ ), $\$: 19.0 \mathrm{~mm}$; tegmen length $\sigma: 20.1-22.8 \mathrm{~mm}$ (mean $21.5 \mathrm{~mm}$ ), $Q: 25.0 \mathrm{~mm}$; pronotum length $\sigma^{*}: 2.1-2.3 \mathrm{~mm}$ (mean $2.2 \mathrm{~mm}$ ), ९: $2.7 \mathrm{~mm}$; mesonotum length $\sigma^{\circ}: 3.8-3.9 \mathrm{~mm}$, ९ : $4.9 \mathrm{~mm}$; head length $\sigma^{\circ}: 1.6-1.7 \mathrm{~mm}, \odot: 2.0 \mathrm{~mm}$; head width o: $3.8-4.6 \mathrm{~mm}$ (mean $4.1 \mathrm{~mm}$ ), $\%: 4.4 \mathrm{~mm}$; width of pronotal collar $\sigma^{\circ}$ : 4.9-5.6 mm (mean $5.2 \mathrm{~mm}$ ), \&: $6.2 \mathrm{~mm}$.

Distribution (Fig. 1). - B. turgida is distributed in the coastal mountain ranges of western Papua New Guinea.

Etymology. - Turgidus (Lat. swollen) refers to the shape of the aedeagus.

Baeturia furcillata $\mathrm{n} . \mathrm{sp}$.

(Figs. 1, 50-57)

Material examined. - Holotype: "New Guinea NE/Upper
Sepik, Wagu/ $\pm 180 \mathrm{~m}, 5 . v i i .1963$ ” [print]; “'1/2 way between Green/Yellow R." [written]; “R. Straatman/collector/BISHOP" [print], $\sigma$, BPBM. Paratype: same data as holotype, $10^{\circ}$, ZMA. Other material: Irian: New Guinea (W.): Hollandia, ii.1920, 1 o , RMNH; Timmena, Nieuw Guinea Exped. 1903, 7.iv.1903, coll. A. Jacobi, $1 \sigma^{\circ}$, SMD: Waris S. of Hollandia, 450-500 m, 8-15.viii.1959, T.C. Maa, 1 ○", BPBM.

Remarks. - B. furcillata closely resembles $B$. turgi$d a$ in the shape of aedeagus and caudodorsal beak, but $\boldsymbol{B}$. furcillata is distinctly smaller, has a more rounded distal margin of the pygofer and a straight distal margin of the operculum. B. furcillata can be easily separated from other species of the viridis group by the rectangular corner of the lateral pygofer lobe. Females of this species are unknown.

Description. - Body reddish brown, slightly brown speckled. Tegmina 1.1-1.2 times as long as total body length. Abdomen 1.2-1.4 times as long as head and thorax together.

Head: red-brown, slightly brown speckled or unspeckled. Head 0.9-1.0 times as long as distance between eyes. Postclypeus in dorsal view (Fig. 51) angularly protruding, with strongly convex anterior margin, 1.5-1.8 times as wide as long. Postclypeus distinctly swollen (Fig. 50), with broadly rounded anterior margin (lateral view).

Thorax: Pronotum reddish brown, slightly brown speckled in medial band between medial fissures, and on pronotal collar. Mesonotum greybrown, unspeckled, tinged with red on cruciform elevation, in lateral bands and in triangular area in front of elevation. Two distinct black spots in front of cruciform elevation.

Tymbal organs: Six parallel sclerotized ridges spanning the tymbal from dorsal to ventral margin and a partly developed 7 th ridge, along proximal tymbal margin, reaching from dorsal margin to about half the tymbal width. Six short intercalary ridges are vaguely discerned. Tymbal bright red between ridges and at margins.

Operculum (Fig. 52): Very short and erect, angular. Lateral margin short and slightly concave, bending angularly into straight distal margin. Medial margin straight. Distomedial corner rounded. Operculum only partly covering tymbal cavity in ventral view, its medial edge not reaching sternite 


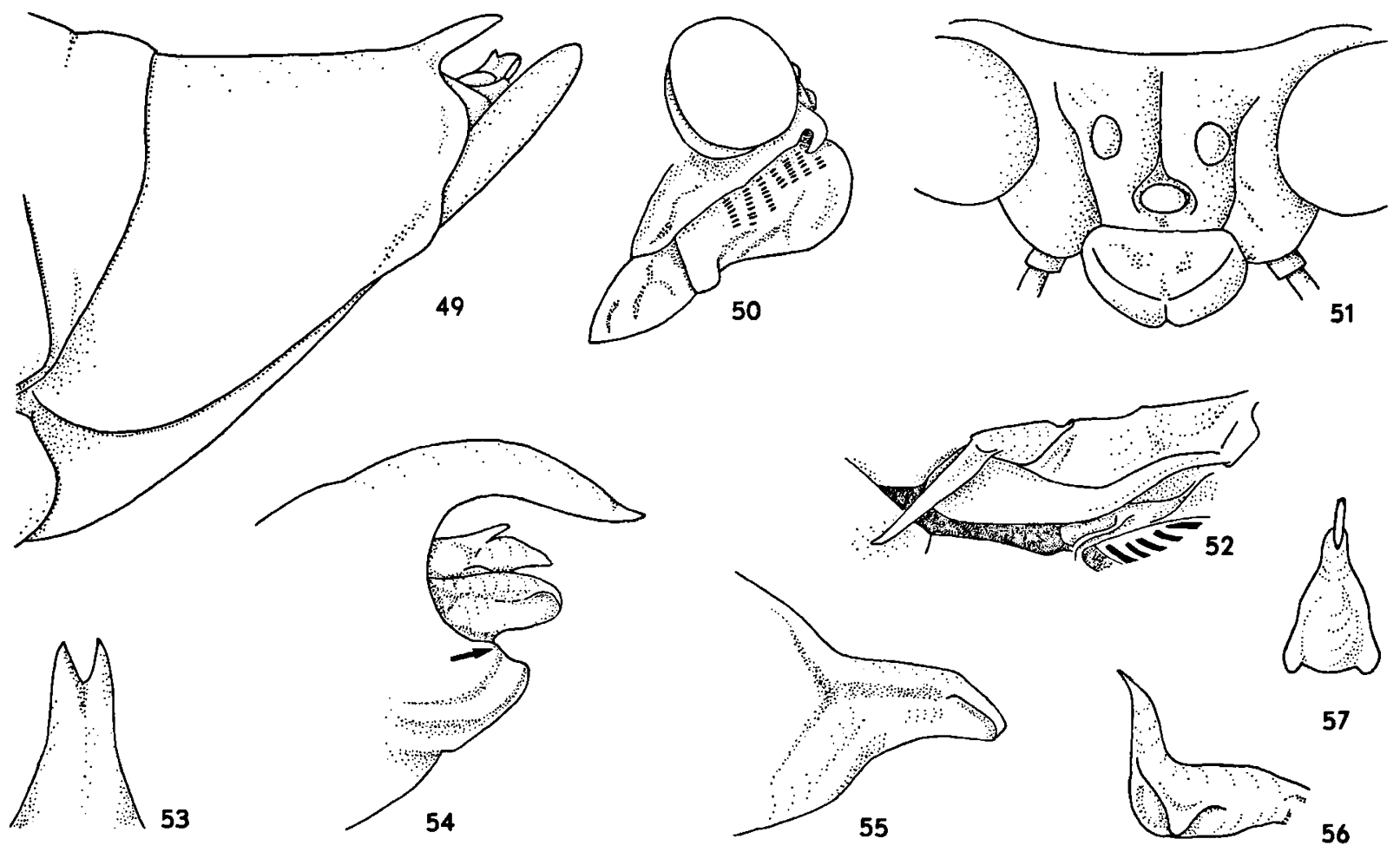

Figs. 49-57. 49, Baeturia turgida n. sp.: female genital segment. Figs. 50-57, Baeturia furcillata n. sp.: 50, head in lateral view, holotype; 51 , head in dorsal view, holotype; 52, operculum, holotype; 53, caudodorsal beak in dorsal view, holotype; 54 , pygofer in lateral view, holotype (arrow indicating angular corner just above apex of lateral pygofer lobe); 55, clasper, holotype; 56, aedeagus in lateral view, holotype; 57, aedeagus from behind, holotype.

2. Meracanthus distinctly reaching beyond operculum.

Abdomen: Red-brown and unspeckled. Slightly darkened in middorsal band. Segmental hind margins 3-7 orange red. A distinct lateroventral row of dark spots on segments 3-8.

Male genitalia: Pygofer in lateral view (Fig. 54) quite different from that of the two preceding species, more resembling that of $B$. brongersmai, $B$. lorentzi, and $B$. viridis. Distal margin of pygofer strongly concave, almost continuously rounded from straight margin of caudodorsal beak towards apices of protuberances on lateral pygofer lobes. Curvature of distal margin not continuous to apex of protuberance (as described for $\boldsymbol{B}$. viridis, $\boldsymbol{B}$. brongersmai and $B$. lorentzi), but bending angularly down to this apex, forming a rectangular corner on lateral pygofer lobe (Fig. 54, arrow). Caudodorsal beak in dorsal view (Fig. 53) as in B. turgida, broad and bifurcate, ending in two sharp spines, but distinctly shorter. Protuberances on lateral lobes of pygofer slender, dorsally and ventrally flattened, forming a sharp lateral edge. Protuberances angularly bent upwards at half-length and ending abruptly at rectangular corner on lateral lobe of pygofer. Clasper (Fig. 55) closely resembling that of $\boldsymbol{B}$. turgida, very straight and erect, often standing almost vertically in pygofer. Claspers retracted in pygofer, lateral crest on clasper base hardly visible. Apical part of clasper slender, with large outwards curved ventral hollow, and distinct crest along proximal half of angularly bent dorsal margin. Claspers slightly diverging towards apices. Clasper gradually broadening towards base, not forming angular clasper heel. Aedeagus in lateral view (Fig. 56) broad as in B. turgida, though smaller. Aedeagus globularly swollen between, and distally of, lateral lobes and slightly concave along margin of pore. Aedeagus from behind (Fig. 57) very broad between lateral lobes. Aedeagus pore long, narrow and oval. 
Measurements. - Body length: 14.7-17.3 mm (mean $15.9 \mathrm{~mm}$ ); tegmen length: $18.3-19.6 \mathrm{~mm}$ (mean $18.9 \mathrm{~mm}$ ); pronotum length: 2.1-2.2 mm; mesonotum length: $2.7-3.7 \mathrm{~mm}$ (mean 3.4 $\mathrm{mm}$ ); head length: $1.3-1.6 \mathrm{~mm}$ (mean $1.4 \mathrm{~mm}$ ); head width: 3.5-3.7 mm (mean $3.6 \mathrm{~mm}$ ); width of pronotal collar: 4.4-4.8 mm (mean $4.6 \mathrm{~mm}$ ).

Distribution (Fig. 1). - B. furcillata seems to be restricted to northeastern Irian Jaya and northwestern Papua New Guinea.

Etymology. - Furcillatus (Lat. forked) refers to the bifurcate caudodorsal beak.

\section{Baeturia karkarensis n. sp.}

(Figs. 1, 58-65)

Material examined. - Holotype: "New Guinea NE/Karkar I., Kurum/Bagiai Crater Trail/240-750 m, viii.68" [print]; "N.L.H. Krauss/collector/BISHOP MUSEUM" [print], o', BPBM. Other material: Karkar I., Kaul, 180-240 m, ii-viii.1968, N.L.H. Krauss, 1 \&, BPBM.

Remarks. - B. karkarensis is described after one male only, while a female from the same area might belong to the species. $B$. karkarensis closely resembles $B$. turgida, but is much larger, has longer and broader opercula, and its caudodorsal beak is not sharply bifurcate, but slightly concave at apex. The holotype has nine apical areas in the tegmina; the female, however, has the normal number of eight. Furthermore, the female has a distinctly broader postclypeus, which makes it doubtful whether it belongs to this species at all.

Description of male. - Body red-brown, slightly brown speckled on head, thorax, and dorsal parts of abdomen. Tegmen 1.1 times as long as total body length. Abdomen 1.6 times as long as head and thorax together.

Head: Ochraceous brown, slightly dark brown speckled all over. Head 1.0 times as long as distance between eyes. Postclypeus in dorsal view angularly protruding and 1.6 times as wide as long (cf. Fig. 51), anterior margin broadly rounded. Postclypeus distinctly swollen, anterior margin (lateral view) broadly rounded.
Thorax: Pronotum ochraceous, speckled all over, but speckling darker and more intense in reddish medial band. Mesonotum greyish brown and slightly brown speckled, reddish tinged in front of reddish cruciform elevation. Two distinct dark spots in front of elevation.

Tymbal organs: Six parallel sclerotized ridges spanning the tymbal, from dorsal to ventral margin and a partly developed 7th ridge, along proximal tymbal margin, reaching from dorsal margin to about half the tymbal width. Six short intercalary ridges are vaguely discerned. Tymbal bright red between ridges and at margins.

Operculum (Fig. 59) closely resembling that of $\boldsymbol{B}$. turgida, but distinctly longer, and almost flat against body. Distal part of male operculum angular, almost oblong, only partly covering tymbal cavity in ventral view. Lateral margin short, bending into long and concave distal margin. Distomedial margin long and slightly convex, making almost right angle with straight medial margin. Distomedial edge of operculum just reaching margin of $a b$ dominal segment 2. Meracanthus erect and reaching to less than half operculum length.

Abdomen: red-brown and strongly inflated. Almost unspeckled, but with some dark middorsal specks, forming a distinct middorsal band. Hind margins of segments 3-7 dark red. A very distinct lateroventral row of dark spots on segments 3-8.

Male genitalia: Pygofer in lateral view (Fig. 58) closely resembling that of $B$. turgida. Distal margin of pygofer straight, making a sharp angle with almost straight margin of caudodorsal beak, and concavely bending into straight margin of upwards directed protuberances. Caudodorsal beak in dorsal view (Fig. 62) stout and truncate at apex. Lateral lobes of pygofer with straight but slightly upwards directed protuberances. These protuberances are slightly shorter than in $B$. turgida, slender and narrowly rounded at apex. Claspers (Fig. 63) very straight and erect, and directed backwards. Claspers in very prominent position, lateral crest on clasper base clearly visible. Apical part of clasper slender, with large outwards curved ventral hollow, and weak crest along proximal half of dorsal margin. Claspers slightly diverging towards apices, gradually broadening towards base, not forming 

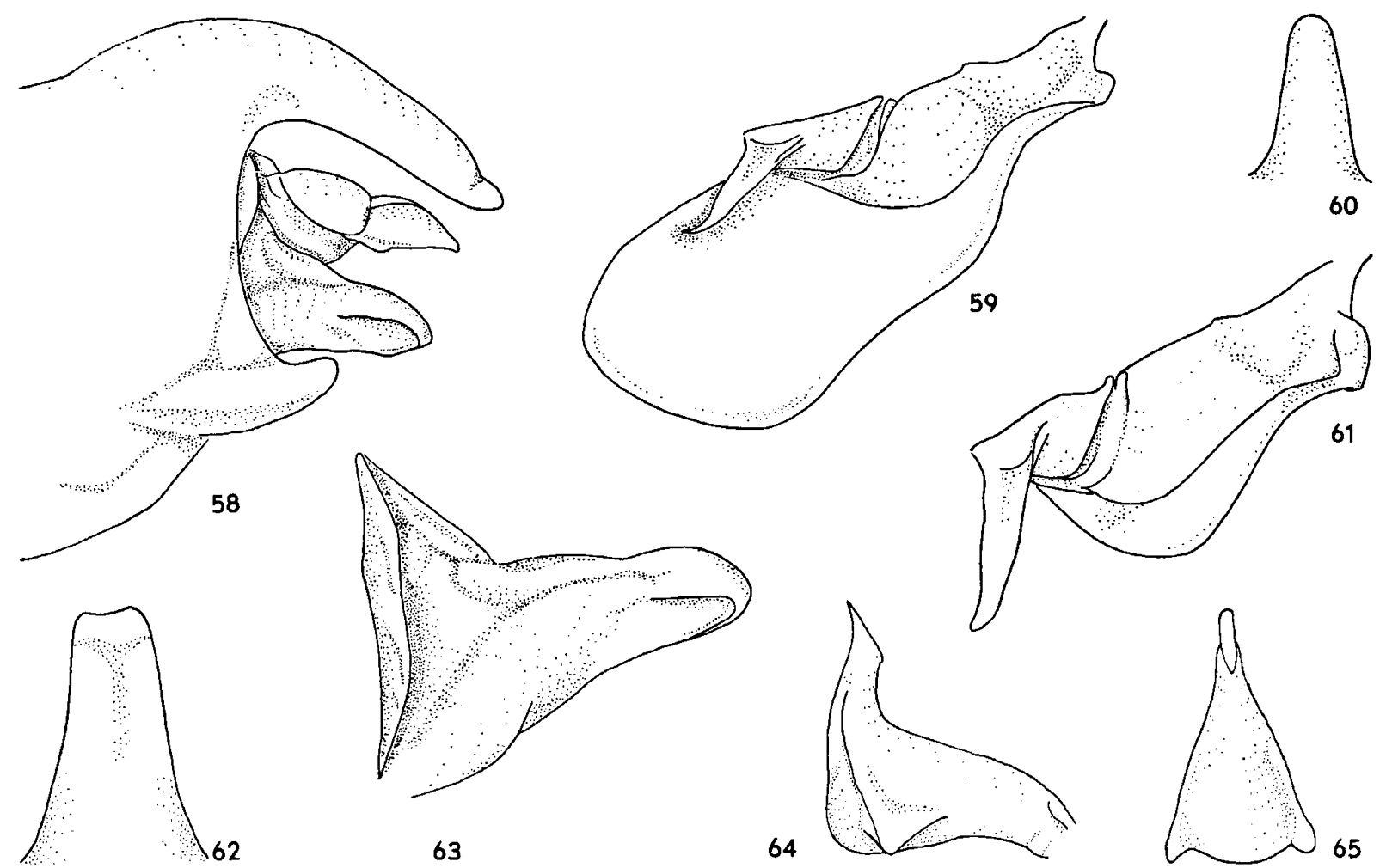

64
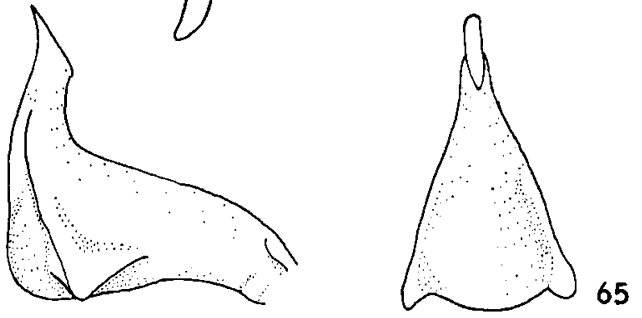

Figs. 58-65. Baeturia karkarensis n. sp.: 58, pygofer in lateral view; 59, male operculum; 60, female caudodorsal beak in dorsal view; 61, female operculum; 62, male caudodorsal beak in dorsal view; 63, clasper; 64, aedeagus in lateral view; 65, aedeagus from behind.

angular clasper heel. Aedeagus in lateral view (Fig. 64) broad as in B. turgida, globularly swollen between, and distally of, lateral lobes and slightly concave along margin of pore. Aedeagus from behind (Fig. 65) extremely broad between lateral lobes. Aedeagus pore slender oval.

Note. - The only available female from Karkar Island somewhat deviates from the male, especially in the shape of the postclypeus, and it is therefore not certain that it belongs to this species. This female, however, seems not to belong to any other known species of Baeturia. The female is greyish brown and densely speckled all over the body, smaller than the male, but with more robust head and thorax, and longer tegmina. Tegmina 1.2 times as long as body length. Abdomen 1.1 times as long as head and thorax together. Postclypeus much broader than in male, oblong and 2.0 times as wide as long. Operculum (Fig. 61) short, sickle-shaped and erect. Lateral margin of operculum long and almost straight, distal and medial margins almost continuously convex. Abdomen brown, dark brown speckled. Segmental hind margins ochraceous or reddish. A distinct lateroventral row of darkened spots on segments 3-7. Ovipositor sheaths reaching just beyond apex of caudodorsal beak. Caudodorsal beak (Fig. 60 ) rounded at apex.

Measurements: Body length $\sigma: 26.6 \mathrm{~mm}$, $९: 23.6 \mathrm{~mm}$; tegmen length $\sigma: 27.8 \mathrm{~mm}, Q: 28.9 \mathrm{~mm}$; pronotum length $\sigma: 2.8 \mathrm{~mm}$, ᄋ: $3.3 \mathrm{~mm}$; mesonotum length $\sigma: 5.5 \mathrm{~mm}, \& ; 5.9 \mathrm{~mm}$; head length $\sigma: 1.8 \mathrm{~mm}, \&: 2.2 \mathrm{~mm}$; head width $\sigma^{\circ}: 4.9 \mathrm{~mm}, \&: 5.6$ $\mathrm{mm}$; width of pronotal collar $\sigma^{\circ}: 6.8 \mathrm{~mm}, \circ: 7.8 \mathrm{~mm}$.

Distribution (Fig. 1). - B. karkarensis is possibly endemic to Karkar Island, off the north coast of Papua New Guinea. 


\section{Acknowledgements}

For the loan of material I wish to thank the following persons and institutions: Dr. M. Amir (MZB); Dr. R. Emmrich (SMD); Dr. U. Göllner-Scheiding (ZMB); Dr. A.H. Kirk-Spriggs (NMW); Dr. W.J. Knight and Mr. M.D. Webb (BMNH); Mr. G.M. Nishida (BPBM); Mr. J. van Stalle (KBIN); and Mr. J. van Tol (RMNH). I would like to thank Mr. G. Verlaan and Mr. D.A. Langerak for technical assistance. I am indebted to Prof. Dr. J.H. Stock and Dr. J.P. Duffels (Institute of Taxonomic Zoology, University of Amsterdam) for their critical reading and comments on the manuscript.

\section{References}

Anonymous, 1938. Atlas van tropisch Nederland: [i-ix], maps 1-31b, legenda 1-31b, 1-17 (Koninklijk Nederlandsch Aardrijkskundig Genootschap \& Topografische Dienst in Nederlandsch-Indië, Amsterdam/Batavia).

Anonymous, 1966. List of New Guinea localities: 1-19 (Bernice P. Bishop Museum, Honolulu).

Anonymous, 1968. The Times atlas of the world: i-xliii, 1-272, pls. 1-123 (Times Newspapers Ltd., London).

Blöte, H.C., 1960. The genus Baeturia Stal as represented in New Guinea (Homoptera, Cicadidae). Zool. Meded. Leiden, 37: 61-80.

Boer, A.J. de, 1982. The taxonomy and biogeography of the nasuta group of the genus Baeturia Stall, 1866 (Homoptera, Tibicinidae). Beaufortia, 32: 57-78.

Boer, A.J. de, 1986. The taxonomy and biogeography of the conviva group of the genus Baeturia Stål, 1866 (Homoptera, Tibicinidae). Beaufortia, 36: 167-182.
Boer, A.J. de, 1989. The taxonomy and biogeography of the bloetei group of the genus Baeturia Stål, 1866 (Homoptera, Tibicinidae). Beaufortia, 39: 1-43.

Boer, A.J. de, 1990. Aedeastria, a new cicada genus from New Guinea, its phylogeny and biogeography (Homoptera, Tibicinidae), preceded by a discussion on the taxonomy of New Guinean Tibicinidae. Beaufortia, 40: 63-72.

Duffels, J.P., 1977. A revision of the genus Diceropyga Stall, 1870 (Homoptera, Cicadidae). Monografieën ned. ent. Veren., 8: 1-227.

Duffels, J.P., 1986. Biogeography of Indopacific Cicadoidea, a tentative recognition of areas of endemism. Cladistics, 2(4): 318-336.

Duffels, J.P. \& A.J. de Boer, 1990. Areas of endemism and composite areas in East Malesia. In: P. Baas, C. Kalkman \& R. Geesink (eds.), The plant diversity of Malesia: Proceedings of the Flora Malesiana symposium commemorating Professor Dr. C.G.G.J. van Steenis, Leiden, August 1989: 249-272 (Kluwer Academic Publishers, Dordrecht).

Duffels, J.P. \& P.A. van der Laan, 1985. Catalogue of the Cicadoidea (Homoptera, Auchenorhyncha) 1956-1980. Series Ent., 33: i-xvi, 1-414.

Hamilton, W., 1979. Tectonics of the Indonesian region. Geol. Surv. prof. Pap., 1078: i-ix, 1-345.

Holloway, J.D., 1979. A survey of the Lepidoptera, biogeography and ecology of New Caledonia. Series Ent., 15: i-xii, 1-588.

Holloway, J.D., 1984. Lepidoptera and the Melanesian Arcs. In: F.J. Radovsky, P.H. Raven \& S.H. Sohmer (eds.), Biogeography of the tropical Pacific, proceedings of a symposium: 129-169 (Association of Systematics Collection, Lawrence, U.S.A).

Received: 1 March 1991 